\title{
Alzheimer's Disease: Mechanism and Approach to Cell Therapy
}

\author{
Takashi Amemori ${ }^{1, *}$, Pavla Jendelova ${ }^{1,2}$, Jiri Ruzicka ${ }^{1}$, Lucia Machova Urdzikova ${ }^{1}$ and \\ Eva Sykova ${ }^{1,2}$
}

Received: 14 September 2015 ; Accepted: 26 October 2015 ; Published: 4 November 2015

Academic Editor: Kurt A. Jellinger

1 Department of Neuroscience, Institute of Experimental Medicine, Academy of Sciences of the Czech Republic, Videnska 1083, 14220 Prague 4, Czech Republic; jendel@biomed.cas.cz (P.J.); j.ruzicka@biomed.cas.cz (J.R.); urdzikl@biomed.cas.cz (L.M.U.); sykova@biomed.cas.cz (E.S.)

2 Department of Neuroscience, 2nd Faculty of Medicine, Charles University, V Uvalu 84, 15006 Prague 5, Czech Republic

* Correspondence: amemori@biomed.cas.cz; Tel.: +420-241-062-619

\begin{abstract}
Alzheimer's disease (AD) is the most common form of dementia. The risk of $\mathrm{AD}$ increases with age. Although two of the main pathological features of $\mathrm{AD}$, amyloid plaques and neurofibrillary tangles, were already recognized by Alois Alzheimer at the beginning of the 20th century, the pathogenesis of the disease remains unsettled. Therapeutic approaches targeting plaques or tangles have not yet resulted in satisfactory improvements in AD treatment. This may, in part, be due to early-onset and late-onset $\mathrm{AD}$ pathogenesis being underpinned by different mechanisms. Most animal models of $\mathrm{AD}$ are generated from gene mutations involved in early onset familial $\mathrm{AD}$, accounting for only $1 \%$ of all cases, which may consequently complicate our understanding of $\mathrm{AD}$ mechanisms. In this article, the authors discuss the pathogenesis of $\mathrm{AD}$ according to the two main neuropathologies, including senescence-related mechanisms and possible treatments using stem cells, namely mesenchymal and neural stem cells.
\end{abstract}

Keywords: Alzheimer's disease; amyloid- $\beta$; Tau; mesenchymal stem cells; neural stem cells

\section{Introduction}

The first case of Alzheimer's disease (AD) was observed by Alois Alzheimer in 1901, with the histological findings, including "plaques" and "tangles" in the upper cortical layer, published in 1907 [1]. Oskar Fischer also found and described neurite plaques in senile dementia cases in the same year [2]. Fischer's name had almost vanished from the history of AD until his contributing works were recounted and recognized by Michel Goedert in 2009 [3] and at the 9th International Conference on Alzheimer's and Parkinson's diseases held in Prague the same year. Alzheimer's works, including his clinical notes and brain slides, were rediscovered by Maurer, Volk and Gerbaldo in 1995 (published in 1997) [4], and by Graeber and his group in 1992 and 1997 (published in 1997 and 1998) [5,6], respectively. Alzheimer's first AD patient was Auguste Deter, a 51 year old female. Rediscovered histological sections have revealed her genetic background; she had a $\varepsilon 3 / \varepsilon 3$ Apolipoprotein E (APOE) genotype [6] and a presenilin 1 mutation [7]. However, the latter finding has not been supported by subsequent study [8].

Alzheimer's disease begins with memory loss of recent events (short-term memory impairment) and finally robs the patients of their sense of self. AD is involved in $50 \%-70 \%$ of dementia cases, and nearly half of people over the age of 85 suffer from it $[9,10]$. The disease poses a great threat to older individuals and their families, becoming a serious social problem with increasing longevity. AD is characterized by two main pathological findings in the brain: Senile plaques (SPs) and neurofibrillary 
tangles (NFTs). The former are extracellular aggregates composed of amyloid $\beta$ (A $\beta$ ) peptides, while the latter are intracellular aggregates composed of hyperphosphorylated Tau protein.

In this review, we first describe recent findings concerning any genetic involvement in $\mathrm{AD}$ pathogenesis. Following this, our current knowledge of SPs and NFTs in AD pathogenesis is described together with immunotherapeutic efforts. To further understand the causal mechanisms of SPs and NFTs, metabolic changes accompanying advancing age and during AD development are considered, focusing on glial involvement in AD development. For the consideration of future research, there are a few words of caution concerning the use of animal models of AD, including their differences compared to human AD patients. Finally, stem cells in AD brains and their therapeutic potential are discussed.

\section{Gene Mutations Related to Early-Onset and Late-Onset AD}

Early-onset AD (EOAD), defined as occurring before 65 years of age, accounts for less than $10 \%$ of AD cases. EOAD with a family link is referred to as familial AD (FAD), most cases of which are linked to autosomal dominant inherited gene mutations: Amyloid precursor protein (APP) $(16 \%$ of FAD), presenilin 1 (PSEN1) (30\%-70\% of FAD) and presenilin 2 (PSEN2) (less than $5 \%$ of FAD) [11]. $\mathrm{AD}$ inherited with these genes is defined as autosomal-dominant AD (ADAD) [12]. Such autosomal dominant AD accounts for approximately $1 \%$ of all AD cases. Mutation of the APP gene facilitates A $\beta$ production whilst that of PSEN 1 and PSEN2 increases the production of $A \beta_{42}$ via $\gamma$-secretase $[13,14]$.

Late-onset AD (LOAD) occurs after 65 years of age and is also known as sporadic AD (SAD), accounting for $85 \%-95 \%$ of $\mathrm{AD}$ cases [15]. The APOE gene is the largest known genetic risk factor for SAD. APOE is the product of a single gene on chromosome 19 [16], is mainly produced by astrocytes and microglia in the brain, and is involved in the transportation and metabolism of cholesterol and triglycerides [17,18]. Three APOE isoforms (APOE2, APOE3, APOE4) with the following population prevalences have been identified as contributing to the disease: APOE3 $(77 \%-78 \%)>$ APOE4 $(14 \%-16 \%)>$ APOE2 $(7 \%-8 \%)$ [19]. The APOE gene exists as three different alleles in humans $(\varepsilon 2, \varepsilon 3$ and $\varepsilon 4)$. The $\varepsilon 4$ allele of APOE is recognized as a major risk factor for $\mathrm{SAD}$, increasing the risk of developing the disease by three-fold in heterozygotes and by 15 -fold in homozygotes. [20,21]; however, in sporadic cases its estimated prevalence risk is only $10 \%-20 \%$ [22]. A large scale meta-analysis was performed using a genome-wide association study (GWAS), which revealed 22 associated genetic loci linked to SAD [23-25], Detailed descriptions of these genes have been published elsewhere [26-37].

SAD is the most common form of AD. In addition to APOE, dozens of other genetic risk factors for SAD have been identified, although further evidence is required to evaluate newly identified risk factors in terms of their functional roles and contributions. Cholesterol metabolism and immune response have been indicated as the primary causes of SAD among many categories used in one analysis [38]. TREM2, CD33 and CR1 are related to the microglial phagocytosis of $A \beta[28,31,32]$. These additional genetic findings may offer a key to understanding the sophisticated pathological mechanisms of $\mathrm{AD}$, giving us an opportunity to create a suitable animal model of SAD.

\section{Amyloid Plaques and Immunotherapy}

Amyloid precursor protein (APP) appears to play an important role in neural development and neurogenesis. It is cleaved by $\beta$-secretase (BACE1) at the $N$-terminal of an $A \beta$ sequence to form a 99 amino acid fragment $C 99$, which is subsequently cleaved by $\gamma$-secretase producing an $A \beta$ fragment and APP intracellular domain (AICD) [39]. This process produces A $\beta$ consisting of 36 to 43 amino acids; $A \beta_{40}$ is the most abundant species ( $90 \%$ of the total $A \beta$ peptide) in normal and $\mathrm{AD}$ brains followed by $\mathrm{A} \beta_{42}$ [40]. An extracellular fragment of APP binds death receptor 6 (DR6) or p75NTR (DR6 has a much higher affinity for APP than does p75NTR) and triggers the degeneration of cell bodies [41]. 
Most research is directed at two particular targets: Amyloid accumulation and tangle formation. The former is targeted according to the amyloid cascade hypothesis [42-45], which is based on the deposition of $\mathrm{A} \beta$ protein, the main component of the plaques that drive $\mathrm{AD}$, leading to NFTs, neuronal loss, vascular damage, and dementia [44]. However, amyloid plaque burden poorly correlates with disease severity [46]. On the other hand, elevated levels of $A \beta_{40}$ and $A \beta_{42}$ correspond to the degree of cognitive decline when a single formic acid extract is used [47], suggesting that soluble A $\beta$ s, such as amyloid oligomers, correlate with disease severity [48]. Amyloid oligomers have been shown to impair long-term potentiation (LTP) and cognitive function, and the synaptotoxicity of amyloid oligomers has been suggested [49,50]. However, careful analysis is required to examine oligomeric toxicity and to compare data obtained from different laboratories because the ubiquitous protein fractionation technique SDS-PAGE is not a reliable method for analyzing amyloid oligomers. SDS may artificially induce A $\beta$ aggregation and conformational changes [51]. Memory loss at the early stage of $\mathrm{AD}$ may be partly due to the synaptic dysfunction induced by amyloid oligomers which cause perturbations in insulin signaling [52,53]. The binding of $A \beta$ oligomers to the cellular prion protein $\left(\mathrm{PrP}^{\mathrm{C}}\right)$ activates Fyn, resulting in the disruption of synaptic plasticity $[54,55]$. $A \beta$ dimers isolated from AD brains induce Tau phosphorylation and NFTs [56]. A $\beta$ oligomers bind to Fz receptors, resulting in the inhibition of Wnt signaling, which in turn causes Tau phosphorylation and neurofibrillary tangles [57]. A $\beta$ induces oxidative stress, endoplasmic reticulum (ER) stress, calcium stress and Tau phosphorylation, and sensitizes neurons to excitotoxicity [58]. Although these findings underpin the amyloid cascade hypothesis, it nevertheless only accounts for less than $1 \%$ of AD cases. Importantly, data supporting the amyloid cascade hypothesis come mainly from studies using animal models of ADAD.

Active immunization has been used to treat $A D$, by targeting $A \beta$. The trial was halted by the development of aseptic meningoencephalitis, which occurred in $6 \%$ of patients and was caused by a T-cell-mediated autoimmune response. $\mathrm{A} \beta$ was cleared from the neocortex, but neither cognitive improvement nor changes in Tau pathology, cerebral amyloid angiopathy, or A $\beta$ oligomers were observed [59]. In order to prevent the side effects induced by active immunization, passive immunization was utilized. There were no significant clinical improvements in Phase 1 and 2 studies using a single dose of solanezumab, an IgG1 antiamyloid monoclonal antibody that binds to soluble monomers and lower-molecular-weight $A \beta$ oligomer species, but not to fibrillary $A \beta$ species or higher-molecular-weight $A \beta$ oligomer species [60,61]. Repeated treatment with solanezumab did not show a significant benefit in data obtained from patients with mild or moderate AD dementia, but a slowing of cognitive decline was found in approximately $34 \%$ of mild AD patients, diagnosed as ADAS- $\log _{14}$ (AD Assessment Scale Cognitive subscale) $[60,62,63]$, supporting the suggestion that amyloid-targeted therapy could be more effective when applied at earlier stages of AD or before visible symptoms appear $[64,65]$. Specific immunization of the neurotoxic A $\beta$ oligomer might be beneficial to circumvent inhibitory damage to the protective physiological benefits of $A \beta$. Further on-going studies should reveal the efficacy of these antibodies in the treatment of AD patients. $A \beta$ immunotherapies currently used in clinical trials have been described in detail by Goure and colleagues (2014) [61].

\section{Tau Pathology and Immunotherapy}

Tau is a microtubule-associated protein (MAP) required for stabilizing microtubules and neurite outgrowth [66,67]. Normal Tau interacts with tubulin, facilitates its assembly into microtubules and stabilizes their structure [66]. Tau-based neurofibrillary pathology is found in more than 20 neurodegenerative diseases [68]. Phosphorylation of Tau within the microtubule binding repeats $(\mathrm{R})$ is necessary for appropriate neurite outgrowth. The ratio of $3 \mathrm{R}$ and $4 \mathrm{R}$ Tau isoforms is generally 1:1 in the adult brain, but deviations from this ratio may cause Tauopathies (Tau pathologies) [69].

Hyperphosphorylated Tau spontaneously aggregates into paired helical filaments (PHF), which can subsequently form NFTs. In AD, hyperphosphorylated Tau accumulates, prompting its 
dissociation from microtubules, thus leading to their destabilization and the disruption of neuronal transport [70]. The number of NFTs correlates with the extent of disease progression in AD but does not correspond to neuronal loss, since memory deficits and neuronal loss precede the formation of NFTs [71]. Tau oligomers, rather than fibrillar aggregates, may be cytotoxic [72]. One study found that learning and memory deficits were exacerbated with increasing Tau oligomers in AD [73]. Synaptic loss and microglial activation precede the onset of NFT formation, reflecting the impaired axonal transport that occurs as a result of Tau hyperphosphorylation [74,75]. Tau pathology is always present in the entorhinal cortex of all people over 75 years of age [76]. The MAP Tau gene itself has been found in different diseases with different forms of dementia other than $\mathrm{AD}$ and has been reportedly located on human chromosome 17q21 in frontotemporal dementia with parkinsonism [77], subsequently referred to as frontotemporal dementia and parkinsonism linked to chromosome 17 (FTDP-17). This mutation of Tau induces NFTs composed of hyperphosphorylated Tau protein. Forty four pathogenic MAP Tau mutations have been described in over 100 families [78].

In SAD, Tau-related pathologies are not believed to be downstream of $\mathrm{A} \beta$ pathologies, but rather amyloid and Tau pathologies may have dual independent pathways [79]. Phosphorylated Tau is initiated in the brainstem, in particular in the locus coeruleus, followed by the medial temporal lobe, limbic structures, association cortex, and the primary cortices. Conversely, A $\beta$ deposition occurs first in the association cortex and thereafter develops to the lower cortical areas, deep gray matter, brainstem, and cerebellum [80]. It is likely that tangle formation occurs independently of the presence of $A \beta$. This was indicated in one study by the fact that $A \beta$ vaccination almost entirely cleared $A \beta$, whilst the severe and progressive tangle pathology remained and clinical improvement was not achieved [81]. This finding encourages the development of AD treatments targeting Tau pathologies. Active immunization using Tau epitopes has been performed to block or reduce Tau pathology, but it also carries the risk of encephalitis or neuronal apoptosis [82]. Passive immunization trials have shown that Tau related pathology could be reduced when the antibody was administered at early time points prior to the onset of Tau pathology $[83,84]$. Passive immunization with anti-Tau antibodies can reduce Tau pathology and delay the development of motor deficits in P301S transgenic mice [84]; such clinical trials are ongoing.

Therapeutic approaches to prevent $A \beta$ accumulation and Tau hyperphosphorylation should not adversely affect their normal protective physiological functions. Low doses of $A \beta$ have been found to enhance LTP and hippocampal acetylcholine production, resulting in memory improvement [85], whilst APP knockout mice have demonstrated functional impairment, having defects in $\mathrm{Ca}^{2+}$-handling, synaptic plasticity and/or neuronal network formation rather than gross structural changes [86]. Tau knockout mice are likely to promote the progression of motor dysfunction with advancing age [87].

\section{Metabolic Changes in Senescence and AD}

\subsection{Protein Metabolism in $A D$}

A functional decline in protein homeostasis (proteostasis) causes an accumulation of damaged and misfolded proteins in aging cells and diseases such as AD [88]. The endoplasmic reticulum (ER) is the major site of protein synthesis. Unfolded or misfolded proteins accumulate in the ER lumen leading to ER stress, which triggers a complex network of signaling events and cellular processes, known as the ubiquitin-proteasome system (UPS), which relieves stress and re-establishes homeostasis [89]. UPS involves translational arrest, ER-chaperone induction and ER-associated degradation (ERAD). ERAD can remove unfolded proteins through retrograde transport from the ER to the cytosol [90]. If the protective mechanism of the UPS fails to recover homeostasis, pro-apoptotic signals cause the death of irreversibly damaged cells, with excessive and prolonged ER stress resulting in apoptotic cell death. An accumulation of unfolded proteins triggers the dissociation of $78 \mathrm{kDa}$ glucose-regulated protein (GRP78) from the major effectors of the UPS, 
including inositol requiring enzyme $1 \alpha$ (IRE1 $\alpha)$, protein kinase RNA-like ER kinase (PERK) and activating transcription factor 6 (ATF6). PERK and IRE1 $\alpha$ are activated by dimerization followed by autophosphorylation. ATF6 translocates to the Golgi apparatus and is cleaved by two proteases, S1P and S2P, to release an active cytosolic fragment (ATF6f) that regulates a subset of UPS target genes involved in ERAD. PERK can phosphorylate $\alpha$ subunits of eukaryotic initiation factor 2 (eIF2 $\alpha$ ), which arrest protein synthesis and alleviate the overload of proteins inside the ER [91]. When stress cannot be alleviated, ATF4 promotes cell death by upregulating transcription factor $\mathrm{C} / \mathrm{EBP}$ homologous protein (CHOP) through BH3-only members of the Bcl-2 family. CHOP induces endoplasmic reticulum oxidoreductin- $1 \alpha(E R O 1 \alpha)$ which activates the inositol trisphosphate receptor (IP3R) stimulating calcium release from the ER, and leading to calcium overload and apoptosis by mitochondrial uptake. Increased ERO1 $\alpha$ induces hyperoxidation in the ER that may promote cell death [92]. Activated IRE1 $\alpha$ can bind tumor necrosis factor (TNF) receptor associated factor 2 (TRAF2), which in turn stimulates apoptosis signal-regulating kinase 1 (ASK1) and leads to the activation of c-Jun N-terminal kinase (JNK) and p38 mitogen-activated protein kinase (p38 MAPK), consequently inducing autophagy and apoptotic cell death $[93,94]$. JNK and p38 MAPK are also involved in Tau phosphorylation [95,96]. Chaperone BiP, PERK and eIF2 $\alpha$ decrease during aging [97]. ER stress induces inflammation via the activation of NF-KB [98], which can activate BACE1 resulting in amyloidogenesis [99]. ER stress can also activate Tau kinase, glycogen synthase kinase $3 \beta$ (GSK-3 $\beta$ ), which enhances NFT formation [100].

The UPS and autophagy systems are indispensable for the maintenance of proteostasis as misfolded and damaged proteins must be efficiently refolded or removed. Chaperones play a key role in the proteostasis system and in sensing misfolded proteins, which are directed to the protein degradation pathways when refolding fails [101]. Almost all aging organisms show a gradual decrease in UPS and autophagy activity [102]. Among the heat shock proteins (HSPs), known as molecular chaperones, HSP90, HSP70, and HSP32, which are increased in the AD brain, induce the production of IL- 6 and TNF $\alpha$ and increase the microglial phagocytosis and clearance of $A \beta_{42}$ by NF-kB and p38 MAPK activation, via Toll-like receptor 4 (TLR4) [103]. HSP22 and HSP27 bind to fibrillar amyloid plaques to inhibit further fibrillarization [101]. Proinflammatory cytokines such as IL-1 and TNF- $\alpha$ facilitate the phosphorylation of small heat shock proteins [104]. GRP78, also known as binding immunoglobulin protein (BiP), is a member of the HSP70 protein family, which regulates APP and A $\beta$ secretion by modulating the interaction between APP, $\beta$-secretase and $\gamma$-secretase. GRP78 is required for stress-induced autophagy and plays a central role in regulating UPS [105].

For stabilization, Tau first binds to the co-chaperone heat-shock cognate protein-70 (HSC70), but if this does not occur, it binds to HSP70 for degradation [106]. Tau can be degraded via the ubiquitin-proteasome and lysosomal pathways. The $\mathrm{C}$ terminus of HSP70-interacting protein (CHIP) is the ubiquitin ligase of Tau. Reduced CHIP levels increase the accumulation of Tau aggregates in transgenic mice and are present in AD brains [107]. HSP27, HSP70 and CHIP can recognize abnormal Tau and reduce its concentration by facilitating its degradation and dephosphorylation [104]. Akt, referred to as protein kinase B (PKB), can hyperphosphorylate Tau directly or indirectly through GSK-3 $\beta$ and PARK1/PARK2, preventing CHIP-induced Tau ubiquitination, and is present in AD at elevated concentrations [108].

\subsection{Cholesterol Metabolism (Lipid Rafts and $\operatorname{Pr} P^{C}$ ) in $A D$}

The human brain contains about $25 \%$ of the body's total cholesterol [109]. Since the blood brain barrier (BBB) prevents the uptake of lipoproteins, brain cholesterol must be derived from de novo synthesis [110]. Alterations in the distribution of lipids within brain cell membranes during aging are considered a risk factor for AD [111]. Ganglionsides, especially GM1, bind with A $\beta$ and convert soluble nontoxic $A \beta$ into aggregated toxic $A \beta$, i.e., the conformational transition from $\alpha$-helix to $\beta$-sheet; this step is considered to be critical in AD development [112]. An increase in cholesterol concentration in neuronal membranes accelerates $A \beta$ binding to GM1 (GA $\beta$ ), which 
subsequently promotes $\mathrm{A} \beta$ fibrillation [113,114]. GA $\beta$-induced amyloidogenesis was suppressed by pretreatment with a sphingomyelin synthase inhibitor. Sphigomyelin is also involved in GA $\beta$ generation [115]. Cholesterol, sphingomyelin, and GM1 are all contained in plasma membrane microdomains known as lipid rafts and are abundant in cholesterol and sphingolipids, serving as a platform for cellular signaling as well as protein-lipid and protein-protein interactions [116,117]. APP, BACE1, the $\gamma$-secretase subunits and $A \beta$ are found in raft domains [118]. Increased cholesterol levels upregulate $\mathrm{A} \beta$ formation, whereas low cholesterol levels relocate the major $\alpha$-secretase, ADAM10, from raft domains to non-raft regions of the membrane, resulting in increased non-amyloidogenic processes $[119,120]$. In contrast, the movement of BACE1 from non-raft to raft domains causes an upregulation of soluble $\beta$-cleaved APP and A $\beta$ production. Cholesterol binds to C99, which promotes amyloidogenic processing and, in turn, causes alterations in cholesterol homeostasis in the Golgi and plasma membrane [121].

APP intracellular domain (AICD) released from APP by PS1-dependent $\gamma$-secretase activity regulates plasmalogen synthesis [122,123]. Reduced plasmalogen levels in the AD brain oppose the inhibitory activity of $\gamma$-secretase, resulting in increased A $\beta$ production. AICD also regulates sphingolipid synthesis via serine palmitoyltransferase and may control the composition of lipid rafts and APP processing [124]. Lipid rafts are components of cell membranes that integrate signaling pathways and regulate physiological cellular function [121]. Lipid destabilization in lipid rafts occurs as an early event in the pathogenesis of AD from the frontal and entorhinal cortices, and may result in the amyloidogenic processing of APP [125]. Membrane ceramides, the major component of lipid rafts facilitate the trafficking of BACE1and $\gamma$-secretase to lipid rafts leading to $\mathrm{A} \beta$ production [126]. $\beta$-Secretase and $\gamma$-secretase are located in cholesterol-rich lipid rafts, while the non-amyloidogenic $\alpha$-secretase is associated with the membrane surface, outside the raft domains. $\beta$-Secretase activity is increased by cholesterol [16]. The amyloid-degrading enzymes neprylisin (NEP) and insulin-degrading enzyme (IDE) are also associated with lipid rafts [127-129], suggesting that lipid rafts may be involved in $\mathrm{A} \beta$ degradation.

The cellular prion protein $\left(\operatorname{PrP}^{C}\right)$ is a normal protein found on cell membranes. It is neuroprotective and plays important roles in defending against oxidative stress and maintaining metal ion homeostasis in the brain [130]. In contrast, in $\mathrm{AD}, \mathrm{A} \beta$ oligomers binding to $\operatorname{PrP}^{\mathrm{C}}$ interrupt the protein's inhibitory effects on BACE1 resulting in increased $A \beta$ production. The binding of $A \beta$ oligomers to $\mathrm{PrP}^{\mathrm{C}}$ activates Fyn, which is a member of the Src family of tyrosine kinases and regulates the internalization and synaptic localization of NR2B-containing NMDAR [131]. Fyn activation induced by $\mathrm{A} \beta$ oligomer-PrPC $\mathrm{P}^{\mathrm{C}}$ complexes drives tyrosine phosphorylation of the NR2B subunit of NMDARs, which is also localized in lipid rafts [120]. NMDAR phosphorylation in turn causes LTP inhibition, oxidative stress, apoptosis and calcium dysregulation, resulting in neuronal loss and memory impairment $[51,132,133]$. A $\beta$ oligomer-mediated early synaptic dysfunction depends on the phosphorylation of NMDAR subunits [134]. $\operatorname{PrP}^{\mathrm{C}}$ and Fyn are located at synapses and enrich the postsynaptic density (PSD). However, $\mathrm{PrP}^{\mathrm{C}}$ is localized on the outer surface of the membrane where it attaches to the lipid bilayer via a glycosylphosphatidylinositol (GPI) anchor, whereas Fyn is present on the inner side of the membrane. Lipid rafts provide the opportunity for the interaction of $\mathrm{PrP}^{\mathrm{C}}$ and Fyn [135]. Age- and disease-dependent disruption of lipid rafts may result in the inability of $\mathrm{PrP}^{\mathrm{C}}$ to control BACE1 [124]. Furthermore, since lipid rafts are strongly concentrated in hippocampal neurons, the interaction of $\mathrm{A} \beta$ oligomer and $\operatorname{PrP}^{\mathrm{C}}$ may induce memory deficits [136]. The $\mathrm{A} \beta$ oligomer-PrPC-Fyn pathway seems to link to synaptic loss and memory impairment, the most prominent aspects of AD. On the other hand, some studies have cast doubt on the involvement of $\operatorname{PrP}^{C}$ in memory impairment. Ablation or overexpression of $\operatorname{PrP}^{\mathrm{C}}$ had no effect on hippocampal synaptic plasticity and oligomer-induced cognitive impairment $[137,138]$. Recent studies suggest that these conflicting results may be attributed to differences in soluble $\mathrm{A} \beta$, the location of its binding site in $\mathrm{PrP}^{\mathrm{C}}$ and/or the animal models used $[139,140]$. Among soluble $\mathrm{A} \beta$, protofibrils have a high affinity interaction with $\operatorname{PrP}^{\mathrm{C}}$. Treatment with an antibody that binds 
$\mathrm{PrPC}_{93-109}$ prevents neuronal cell death by $\mathrm{A} \beta$ oligomers, but antibodies that bind $\mathrm{PrP}^{\mathrm{C}}{ }_{144-152}$ or $\mathrm{PrPC}_{213-230}$ fail to block $\mathrm{A} \beta$-induced neurotoxicity. Tau [128] and proline-directed serine/threonine kinases, such as cyclin-dependent kinase 5 (Cdk5) [141] and GSK-3 $\beta$ [142] that are recognized as prime mediators in the hyperphosphorylation of Tau, have been detected in lipid rafts. It is possible that lipid rafts may serve as domains between Tau and its related kinases. Cdk5 is activated in neurons by the neuron-specific activator p35 and is involved in brain development and synaptic activity under normal physiological conditions [143]. In AD, various stressors such as ischemia, oxidative stress, mitochondrial dysfunction, neuroexcitotoxicity, $\mathrm{A} \beta$ exposure, calcium imbalance, and inflammation lead to the elevated influx of calcium into the cytoplasm, which in turn activates the calpain-mediated cleavage of p35 to p25 [144]. The half-life of p25 is longer than that of p35. Through its p10 myristoylated N-terminal end, p35 is bound to the membrane, while in contrast p25 localizes to the cell soma because of its lack of p10 [145]. These differences form a more stable and hyperactive Cdk5/p25 complex, which causes aberrant hyperphosphorylation of Tau, leading to neurodegeneration and cell death. Calpain activation leading to p25 accumulation and elevated Cdk5 activity has been found in the AD brain [146]. Fyn activates GSK3 $\beta$ and Cdk5 and can also hyperphosphorylate Tau at tyrosine 18 by itself. This tyrosine phosphorylated Tau has been found in NFTs in the AD brain $[147,148]$. Tau binds and sequesters Fyn to alter its localization in the neuron. This altered Fyn localization may in turn activate Fyn via A $\beta$ [149]. Thus, Tau can interact with Fyn in dendrites, which stabilizes the interaction of NMDAR with the postsynaptic density (PSD) protein PSD-95 and mediates A $\beta$-induced-neurotoxicity [150].

\subsection{Glucose Metabolism in AD}

Up to $50 \%$ of the body's total glucose is consumed in the brain. However, this consumption of glucose decreases with age and in AD [151]. Glucose deprivation is used as an energy deficiency for in vitro induced eIF2 $\alpha$ phosphorylation, which increases BACE1 levels and thereby promotes amyloidogenesis in AD [152,153]. Glucose transporters (GLUT) 1 and 3 play an important role in transporting glucose to neurons [154]. Levels of GLUT1 and GLUT3 decline in $\mathrm{AD}$, which results in decreased uridine diphosphate $N$-acetylglucosamine (UDP-GlcNAc) production derived from glucose via the hexosamine biosynthesis pathway (HBP) [151]. Protein $O$-GlcNAcylation is a post-translational modification that includes the attachment and removal of $O$-linked $\beta$ - $N$-acetylglucosamine $(O-G l c N A c)$ to/from serine and threonine residues of nuclear and cytoplasmic proteins; these processes are regulated by O-GlcNAc transferase (OGT) and O-GlcNAcase (OGA), respectively [155]. OGT and OGA are abundantly distributed in the brain, especially in the hippocampus [156]. Tau phosphorylation is inversely regulated by O-GlcNAcylation [157]. Downregulation of protein phosphatase-2A (PP2A), which regulates the activity of several Tau kinases and impairs brain glucose metabolism, contributes to abnormal hyperphosphorylation of Tau in AD [158]. In AD brains, the level of O-GlcNAcylation was 22\% lower compared to controls [159]. O-GlcNAcylation and PP2A regulate Tau phosphorylation at overlapping though partially different phosphorylation sites [151]. Impaired glucose metabolism leads to decreased Tau O-GlcNAcylation and causes abnormal hyperphosphorylation of Tau, resulting in the NFTs observed in AD. Furthermore, O-GlcNAcylation influences the APP processing, which results in increased non-amyloidogenic processing by facilitating $\alpha$-secretase; with increasing neuroprotective $\alpha$-secretase cleaved from soluble APP fragments, A $\beta$ secretion declines [155]. OGA and OGT in synaptosomes regulate $O$-GlcNAcylation of synaptic proteins. The inhibition of OGA causes increased O-GlcNAcylation of pre-synaptic proteins and enhances LTP, which is related to memory function [160].

\subsection{Oxidative Stress and Metabolism}

Oxidative stress is caused by an imbalance between pro-oxidant and antioxidant systems and is exacerbated during aging and $\mathrm{AD}$. An accumulation of reactive oxygen species (ROS), which is 
particularly characteristic of oxidative stress, is mainly produced by mitochondria and causes damage to lipids, cellular proteins, nucleic acids and glucose. The consequences of such damage are seen as lipid peroxidation, protein oxidation, DNA/RNA oxidation, and glycoxidation [161]. Glutathione is the most prevalent antioxidant in the brain and plays a role in the detoxification of ROS [162]. Levels of glutathione decrease with age [163] and in AD [164]. Decreased intracellular glutathione leads to the release of pro-inflammatory factors TNF- $\alpha$, IL- 6 and nitrite ions, and the activation of P38 MAPK, JNK and NF-KB in microglia and astrocytes [165]. JNK-dependent activation of $\gamma$-secretase is promoted by hydrogen peroxide $\left(\mathrm{H}_{2} \mathrm{O}_{2}\right.$, a source of ROSs), resulting in $\mathrm{A} \beta$ production [166]. Manganese superoxide dismutase (MnSOD) is an antioxidant enzyme that protects mitochondria from oxidative stress. Its inactivation has been observed in an animal model of $A D$, resulting in the promotion of mitochondrial dysfunction [167]. High concentrations of $\mathrm{Cu}, \mathrm{Zn}$ and $\mathrm{Fe}$ have been found around amyloid plaque [168]. Since $A \beta$ is a metalloprotein that can bind $\mathrm{Cu}, \mathrm{Zn}$ and Fe ions [169], this might reflect an accumulation of such metals in the AD brain. Complexes of $\mathrm{A} \beta$ and $\mathrm{Cu} / \mathrm{Fe}$ can generate ROS such as $\mathrm{H}_{2} \mathrm{O}_{2}$, leading to $\mathrm{A} \beta$ toxicity [170]. In particular, the $\mathrm{A} \beta / \mathrm{Cu}$ complex catalyzes tyrosine oxidation by $\mathrm{H}_{2} \mathrm{O}_{2}$ leading to dityrosine crosslinking of $\mathrm{A} \beta$ that contributes to the stabilization of oligomeric species and amyloid fibrils [171]. Levels of dityrosine were found to be elevated in the hippocampus and neocortical regions of the AD brain [172]. In contrast, $\mathrm{Zn}$ seems to rescue cells from toxic conditions by reducing the $\mathrm{Cu}$-dependent formation of $\mathrm{H}_{2} \mathrm{O}_{2}$ [173]. However, the dyshomeostasis of $\mathrm{Zn}$ induced by $\mathrm{A} \beta$ leads to microtubule destabilization and increased Tau phosphorylation [174]. Thus, $A \beta$ can act as both an antioxidant and also a pro-oxidant according to its redox properties. Advanced glycation endproducts (AGEs) are formed by non-enzymatic glucoxidation. The receptor for AGE (RAGE) can bind A $\beta$ as well as AGEs. During $\mathrm{AD}$ progression, the expression of RAGE is upregulated in microglia, neurons and endothelial cells surrounding senile plaques [175]. The binding of AGEs and A $\beta$ to RAGE activates NF- $\mathrm{KB}$, which in turn induces the release of various cytokines such as IL-1, IL-6, and TNF- $\alpha$ [176]. This binding also fosters ROS generation by activating NADPH oxidase (NOX), resulting in AD progression [177]. Levels of RAGE, AGEs and $A \beta$ increase in the hippocampus of $A D$ patients, including the dentate gyrus (DG) and CA3 pyramidal neurons. This finding corresponds with the short-term memory loss in AD patients caused by neuronal dysfunction in the hippocampus [178]. The binding of RAGE with AGEs or $A \beta$ activates BACE 1, resulting in $A \beta$ production [179]. $A \beta$ and AGEs can induce mitochondrial dysfunction leading to neurodegeneration [180]. RAGE is also localized in the BBB and mediates the influx of $A \beta$ into the hippocampus and cortex across the BBB [181,182]. AGEs are likely to foster amyloidosis by forming protease-resistant peptides and proteins, leading to protein deposition, and NFT formation by the glycation of Tau, which may stabilize PHF aggregation [177]. Oxidative stress-mediated JNK activation and decreased Wnt signaling followed by GSK-3 activation are required for the development of $\mathrm{AD}$. Both are connected to the forkhead-box $\mathrm{O}$ (FoxO) response, which is critically involved in the upregulation of antioxidative pathways and apoptosis [183]. Lipid peroxidation induced by $\mathrm{A} \beta$ oligomers in the lipid layer fosters lipid peroxidation products including 4-hydroxy-2-nonenal (HNE), malondialdehyde, F2-isoprostanes, and 2-propyn-1-ol [184]. Among these, HNE has been shown to accelerate the formation of $A \beta$ oligomers and protofibrils; this process in turn leads to lipid peroxidation, which produces more HNE and $A \beta$ oligomers [185]. Increased levels of HNE have been observed in the hippocampus of AD patients [186].

\subsection{Insulin Metabolism and $A D$}

Recently, accumulating evidence has cast a spotlight on type 2 diabetes mellitus as a potent risk factor for $\mathrm{AD}$ development, which is likely to be mediated by insulin and insulin-like growth factors (IGF-1, IGF-2). Insulin receptors (IRs) are distributed over the brain, with high levels detected in the olfactory bulb, cerebral cortex, hippocampus, hypothalamus, and cerebellum [187]. In contrast, IGF-1 receptors (IGF-1Rs) are highly expressed in the cerebral cortex, hippocampus, and thalamus $[188,189]$. Signaling via these receptors exerts an effect on both neuronal and glial 
functions, including glucose metabolism and energy homeostasis [190]. Insulin receptor substrates (IRS) are critical in insulin signaling and contribute to the maintenance of cell growth, cell survival, and cellular metabolism [191]. There are four members: IRS-1, IRS-2, IRS-3 and IRS-4 [192]. IRS-1 and IRS-2 are the main mediators of the IR/IGF signaling pathway [193]; mice deficient in these substrates showed accelerated Tau hyperphosphorylation [194-196]. Similarly, levels of IRs, IGF-1R, IRS-1 and IRS-2 are reduced in AD brains [197], which suggests that reduced insulin and IGF-1 signaling may result in the hyperphosphorylation of Tau by mediating protein phosphatase- $2 \mathrm{~A}$ (PP2A) and glycogen synthase kinase $3 \beta$ (GSK-3 $\beta$ ) [193,196]. Alternatively, this signaling pathway may regulate phosphatidylinositol 3-kinase (PI3K), which in turn activates protein kinase $B(\mathrm{PKB})$ that regulates GSK- $3 \alpha$, which is related to A $\beta$ production and GSK-3 $\beta$, also known as Tau kinase $[198,199]$. The impaired signaling pathway may induce the inactivation of PI3K and PKB and disinhibit GSK-3. During aging, similar reductions occur for neuronal glucose metabolism, insulin levels and IR density [200]. Serine phosphorylation of IRSs inhibits insulin signal transduction and contributes to peripheral insulin resistance [201], which is partly mediated by pro-inflammatory cytokines; prolonged resistance is exacerbated by aging and obesity, resulting in glucose intolerance, hyperlipidemia, hypertension, polycystic ovarian syndrome, and type 2 diabetes mellitus [202]. The pro-inflammatory cytokine TNF- $\alpha$ fosters serine phosphorylation of IRS-1 and IRS-2 via JNK binding with IRS proteins, inhibiting subsequent signaling pathways including PI3K/PKB and PI3K/Akt and leading to amyloid deposits and Tau hyperphosphorylation [202,203]. The phosphorylation of serine residues inhibits insulin-stimulated tyrosine phosphorylation [202], which prevents IRSs from binding to IR and IGF receptors and instead directs IRSs towards proteasomal degradation, leading to insulin/IGF resistance [197]. The impairment of insulin/IGF signaling caused by insulin/IGF resistance, characterized by reduced IR and IGF receptor binding to IRSs and a decreased ability to respond to insulin/IGF stimulation, causes oxidative stress, mitochondrial dysfunction, and inflammation. In turn, ROSs produced by oxidative stress and mitochondrial dysfunction as well as pro-inflammatory cytokines secreted during inflammation exacerbate insulin/IGF resistance, which is characteristic of both AD and type 2 diabetes mellitus [200,204,205]. Brain insulin signaling plays an important role in learning and memory [206] and declines with age [207]. Insulin and IGF-1 can protect neurons against $A \beta$-induced synaptic toxicity $[189,208]$. Similarly, insulin-degrading enzyme (IDE), also known as insulin protease, can degrade $A \beta$ [209]. IDE is controlled via the insulin-PI3K-Akt signaling pathway, the impairment of which leads to a reduction of IDE [210], which also appears to be involved in A $\beta$ accumulation. The APOE $\varepsilon 4$ allele is believed to play an important role in insulin's effects as AD patients without the APOE $\varepsilon 4$ allele showed beneficial effects following memory impairment, whilst those with it had none [211]. Furthermore, IDE in the hippocampus is reduced by approximately $50 \%$ in $\mathrm{AD}$ patients with the APOE $\varepsilon 4$ allele compared to those without it [212]. In light of this, gene expression backgrounds should be taken into account when evaluating the effects of insulin on patients and animal models of AD.

\section{Glia and AD}

Recently, the role of glia in $\mathrm{AD}$ pathogenesis has attracted greater interest due to its growing significance. In this section, the AD-related functions of microglia and astrocytes will be described. In the adult human neocortex, the glia/neuron ratios are 1.32 for females and 1.49 for males. Approximately $75 \%$ of neocortical glial cells are oligodendrocytes, $20 \%$ are astrocytes, and $5 \%$ are microglia. The number of neurons and oligodendrocytes decreases between 20 and 90 years of age by $10 \%$ and $27 \%$, respectively, but that of astrocytes remains constant [213].

\subsection{Microglia}

Activated microglia are observed in $\mathrm{AD}$, characterized by short, thickened and less ramified processes. In the aged human brain, microglia are de-ramified and characterized by fragmented processes and bulbous swellings. However, these age-related morphological changes have not been 
observed in the rodent brain [214]. Microglia have been shown to exert both proinflammatory and anti-inflammatory effects. The former is characterized by the secretion of proinflammatory cytokines, including IL-1 $\beta$, IL- 6 and TNF- $\alpha$, resulting in the impairment of neurogenesis $[215,216]$, while the latter involves the production of GFs such as IGF-1, which stimulates neurogenesis [217]. IL-1 $\beta$ released from microglia also increases Tau phosphorylation through a p38 MAPK pathway [218].

Microglia are regulated by fractalkine and CD200. Fractalkine is a 373 amino acid protein known as chemokine ( $\mathrm{C}-\mathrm{X} 3-\mathrm{C}$ motif) ligand $1\left(\mathrm{CX}_{3} \mathrm{CL} 1\right)$ and is expressed by neurons with particularly high levels seen in hippocampal neurons [219]. It binds to $G$ protein-coupled receptors $\left(C_{3} C R 1\right)$ mainly expressed by microglia [220] and inhibits the production of IL-1 $\beta$, TNF- $\alpha$, IL-6 and inducible NO synthetase (iNOS) in microglia through the PI3K pathway [221,222]. Hippocampal CX3CL1 mRNA expression and CX3CL1 levels significantly decrease with age in correlation with increases in IL-1 $\beta$ concentrations [222]. Thus, $\mathrm{CX}_{3} \mathrm{CL} 1 / \mathrm{CX}_{3} \mathrm{CR} 1$ interaction seems to play an important role in the release of proinflammatory substances from activated microglia. CX $\mathrm{X}_{3} \mathrm{CL} 1$ also protects against excitotoxicity leading to neuronal death through the activation of the ERK1/2 and PI3K/Akt pathways $[223,224]$. The level of plasma soluble $\mathrm{CX}_{3} \mathrm{CL1}$ was markedly higher in patients with mild to moderate $\mathrm{AD}$ than in those with severe $\mathrm{AD}$ [225], and the level of tissue $\mathrm{CX}_{3} \mathrm{CL} 1$ was lower in the hippocampus and the frontal cortex of AD patients [226]. The fractalkine signaling pathway mediates communication between microglia and neurons which is downregulated in AD brains, but further investigation is required to understand the precise mechanism of fractalkine signaling based on the stage of $\mathrm{AD}$.

CD200R is an inhibitory receptor on microglia, which are maintained in a quiescent state by the interaction between CD200R and CD200, a transmembrane glycoprotein expressed on neurons [227]. A deficiency in CD200-CD200R interaction may contribute to chronic inflammation leading to AD progression [228]. There are decreased levels of CD200 in aged rats compared with adults [229] and decreased CD200 mRNA expression in the rat hippocampus accompanying increasing age [230]. A significant decrease of both CD200 and CD200R within the brain, with a specific deficit of CD200R mRNA in the hippocampus and interior temporal gyrus, was observed in AD brains compared with matched non-demented tissue [231]. The activation of TLR2 and TLR4 was exacerbated in CD200-deficient mice and exerted a negative effect on LTP [232]. The interruption of the CD200 and CD200R interaction may induce LTP impairment in the hippocampus leading to dementia.

Microglia are involved in the phagocytosis of $A \beta$ and in the inflammatory responses that play important roles in $\mathrm{AD}$ progression, and are also regulated by $\mathrm{FC}_{\mathrm{C}}$ gamma receptors (Fc $\gamma \mathrm{Rs}$ ) and TYRO protein tyrosine kinase-binding protein (TYROBP, also known as DAP12) [233-235]. There are two fundamental pathways to clear $A \beta$ from the brain. One is mediated by several receptors that are expressed in microglia, including scavenger receptors (SR), formyl peptide-receptor-like 1 (FPRL1), complement receptors, FcRs, and TREM2 [236]. The second pathway involves processing by $\mathrm{A} \beta$-degrading enzymes such as neprilysin (NEP), insulin-degrading enzyme (IDE), matrix metalloprotease (MMP) and cathespin B [237-240]. Microglial clearance of A $\beta$ appears to be dependent on age and also on the stage of the disease since $A \beta$ is more effectively removed in the early stages of $\mathrm{AD}$ [241]. In addition, beclin 1 is known to regulate the retromer complex, which is required to maintain phagocytic receptor recycling and phagocytosis. Beclin 1 deficiency impairs the recycling of the phagocytic receptors CD36 and TREM2. Furthermore, the levels of beclin 1 and retromer protein are significantly reduced in microglia isolated from human AD brains, which may lead to an insufficient microglial phagocytic capacity to clear A $\beta$ [242]. The inflammasome NLRP3, also known as NALP3 or CIAS1, is involved in the A $\beta$-induced activation of caspase- 1 in microglia which in turn mediates the cleavage of IL-1 $\beta$ and IL-18 precursors, leading to the release of IL- $1 \beta$ and IL-18 [243]. The phagocytic activity of microglia is attenuated by pro-inflammatory cytokines such as IFN- $\gamma$, IL-1 $\beta$, and TNF- $\alpha$, which likely skew microglia towards the pro-inflammatory M1 phenotype [244]. NLRP3 activation adversely affects the microglial clearance of $A \beta$, and inhibition of 
NLRP3 can induce microglial phagocytosis and an immunosuppressive M2 phenotype resulting in increased $A \beta$ clearance [245].

\subsection{Astrocytes}

Astrocytes regulate extracellular ionic concentration, water homeostasis and the acid-base balance in the brain, mediate the production and clearance of neurotransmitters, and affect glucose supply, antioxidative defense mechanisms, and synaptic regulation by producing various cytokines, chemokines and growth factors [246-249]. Anti-oxidants in astrocytes (mainly glutathione and ascorbate) protect the brain against oxidative stress [250]. Pro-inflammatory molecules and cytokines produced and released by activated astrocytes can cause the further activation of astrocytes, thus perpetuating inflammatory signaling cycles, and may lead to $A \beta$ production by activating $\beta$ - and $\gamma$-secretases [251,252]. Aquaporin4 is the most abundant water channel in the brain and is widely expressed in the astrocyte plasma membrane [253]. A failure to promote the circulation of interstitial fluid via astrocytic aquaporins may cause an accumulation of misfolded proteins in AD brains [246].

Glutamate is converted to glutamine by glutamine synthetase (GS) in astrocytes. The glutamine is released and taken up into neurons and converted into glutamate by mitochondria glutaminase. $\mathrm{A} \beta_{42}$ and oxidative stress significantly decrease GS activity, especially in the hippocampus and neocortex of the AD brain, resulting in an increase in glutamate levels and prolonged NMDA receptor activation [254]. GLT-1 is oxidatively modified by binding to the lipid peroxidation product HNE. This process is facilitated by excessive $A \beta_{42}$ and leads to the inhibition of glutamate transport and increased extraneuronal glutamate accumulation that consequently results in cell death [255]. AD patients have a significant reduction in glutamate transporter activity, associated with increased excitotoxicity and neurodegeneration [256]. Astrocytes are major players in glutamate uptake in the extracellular space and thus keep extracellular glutamate below toxic levels. TNF $\alpha$ downregulates GLAST/EAAT1 and significantly reduces GS expression, resulting in increased excitotoxicity in neurons in vitro $[257,258]$. An age-dependent decrease in GS-positive astrocytes was reported in the hippocampus of 3xTg-AD mice, and GS expression in astrocytes was reduced in the medial prefrontal cortex of the same transgenic mice by the age of 12 months compared with age-matched controls $[259,260]$. The region-dependent effect of GS should be taken into account when evaluating glutamate neurotoxicity in $\mathrm{AD}$.

Astrocytes are also involved in the clearance of $A \beta$ as well as being a source of $A \beta$. Although neurons are the major source of $A \beta$, microglia and astrocytes appear to produce $A \beta$ peptides [261]. The degradation of $A \beta$ is achieved by NEP, IDE, and MMP [262], which are also expressed by astrocytes [262-264].

The majority of apolipoprotein E (APOE) is synthesized by the liver [265], but it is also partly produced by astrocytes [266] and microglia [267] in the brain. APOE has a receptor-binding site in its $\mathrm{N}$-terminal domain and a lipid-binding site in its C-terminal domain [268]. APOE receptors include low-density lipoprotein receptors (LDLR), LDL receptor-related protein 1 (LRP1), very low-density lipoprotein receptors (VLDLR), and APOE receptor 2 (APOER2) [269]. LDLR and LRP1 are endocytic receptors, whilst VLDL and APOER2 are signaling receptors [270]. LDLR is a cell surface receptor that regulates APOE in the brain and whose gene is the major risk factor for SAD. Deletion of LDLR causes a decrease in $A \beta$ uptake, whereas LDLR overexpression significantly enhances the uptake and clearance of $A \beta$ by astrocytes [271].

Glia are thus deeply involved in metabolic changes and complicated signaling pathways during $\mathrm{AD}$ progression. Although DNA damage in the hippocampal astrocytes of AD brains and an increased population of astrocytes from the frontal cortex of aged individuals and AD patients have been reported [272,273], further intensive studies are required to elucidate their causal relationship to $\mathrm{AD}$ pathogenesis and development and to use their therapeutic potential as a target for $\mathrm{AD}$ treatment and prevention. Once $A \beta$ starts to abnormally accumulate, an inflammatory response and phagocytosis are promoted in microglia and astrocytes in order to clear it. Conversely, persistent 
inflammation facilitates $A \beta$ production, and phagocytic ability is reduced with age or during the late stage of $\mathrm{AD}$, resulting in $\mathrm{A} \beta$ deposits. An age-dependent decline in $\mathrm{A} \beta$ clearance and the augmentation of the inflammatory response by glia are also critical for AD pathogenesis.

\section{Models of AD and Senescence}

\subsection{Animal Models of $A D$}

Most animal models of AD incorporate modifications to three genes related to ADAD (APP, PSEN1 and/or PSEN2). When using these animal models, the following caveats should be kept in mind: (1) cases of ADAD make up less than $1 \%$ of human AD cases; (2) the mechanisms of FAD are different from those of SAD; (3) ADAD can be well explained by the amyloid cascade hypothesis, which is based on amyloid deposition leading to tangle formation; in contrast, SPs and NFTs occur independently in different regions of the brain in SAD; (4) synaptic and neuronal loss, the major cause of human AD symptoms, cannot be addressed in most of these animal models. The 5xFAD animal model co-expresses human APP with the Swedish, Florida and London mutations and human PSEN1 with the M146L and L286V mutations and is known to show neuronal loss, but without NFTs [274]. To induce Tau pathology in an animal model, gene mutations discovered in FTDP-17 are used. The triple transgenic mouse model of AD (3xTg-AD) was generated using three transgenes (APP with the Swedish mutations, PSEN1 with M146V mutations, and Tau with P301L mutations). This animal model shows extracellular $A \beta$ deposits in the frontal cortex at 6 months of age, spreading to the hippocampus by 12 months when Tau pathology appears in the hippocampus; however, no neuronal loss is observed $[275,276]$. Human $A \beta$ can be expressed in $A D$ transgenic mice, but human $C 1 q$ (complement protein) cannot. The activation of human $\mathrm{C} 1$ by human $\mathrm{A} \beta$ is more effective than that of mouse C1 [277].

Further cautions should be considered in regards to the strains used to prepare the transgenic animal models. For example, 3xTg-AD mice were generated from a hybrid of C57BL/ 6 mice and F1 animals of $129 \mathrm{X} 1 / \mathrm{SvJ}$ and 129S1/Sv. We compared spatial reference memory performance using the Morris water maze (MWM) test (see Supplementary Material) in 3xTg-AD $(n=28)$, C57BL/ $6(n=25)$ and $129 \mathrm{~S} 2 / \mathrm{SvHsd}(n=24)$ mice, which were used as the 129 substrain. Figure 1 shows the latencies over 10-days training in the MWM test; the mouse, placed in one of four quadrants of the circular pool, had to find a platform hidden $1 \mathrm{~cm}$ below the water, made opaque using a non-harmful white color, within one minute. Four trials were given to each animal every day. The results obtained from the individual mice at 3 months of age are indicated by different marks. Over the ten-day training period, all C57BL/ 6 mice demonstrated decreased latencies for finding the submerged platform, with a final latency of $19.1 \pm 1.7 \mathrm{~s}$ (mean \pm SEM) (Figure 1A). The majority of C57BL/6 mice demonstrated very similar levels of skillfulness, also illustrated by shortened latencies. In contrast, the results observed in 129S2/SvHsd mice highlight how this strain scarcely learned the task at all during the training period, with their average latencies, indicated by a solid black line, not showing any improved performance in finding the platform (Figure 1B). Their final latency was $37.0 \pm 2.6 \mathrm{~s}$. 3xTg-AD mice showed a similar improvement to that of the C57BL/ 6 mice when performing the task, but individual animals had a very wide variation in latencies compared to C57BL/ 6 mice (Figure 1C). Most of the 3xTg-AD mice could complete the task by decreasing their latency over time, but some of them never learned the task. Their final latency was $18.4 \pm 2.3 \mathrm{~s}$. There were also significant differences between C57BL/ 6 and 129S2/SvHsd mice and between 3xTg-AD and 129S2/SvHsd mice in the last performances $(p<0.01)$. During a probe trial in which the hidden platform was removed, the animals had to place themselves in the quadrant where the platform was previously located within a one-minute time-frame (Figure 2); a stay of less than $15 \mathrm{~s}$ was considered to be random chance. All C57BL/ 6 mice clearly spent the majority of their time in the correct quadrant; the time spent in the correct quadrant (Q3) was $26.2 \pm 1.6 \mathrm{~s}$ (A); In contrast, most of the 129S2/SvHsd mice did not orient themselves towards the correct quadrant and spent a very short amount of time in the 
target area $(10.3 \pm 1.4 \mathrm{~s})(\mathrm{B})$; The transgenic mice spent on average more time in the target quadrant $(22.8 \pm 1.6 \mathrm{~s})$, but individual animals showed wide differences in the time spent in the target area (C). Statistical differences were found between C57BL/6 and 129S2/SvHsd mice and between 3xTg-Ad and 129S2/SvHsd mice in the probe trial $(p<0.01)$. Varying abilities in task performance of the MWM test have been previously described among the substrains of 129 . Some of them, including $129 /$ J, 129/Sc and 129/SvJ, did not show good performance in the MWM test, whilst satisfactory performance was observed in 129/SvEvTac, 129/Ola and 129/Sv [278,279]. Accordingly, to evaluate differences in cognitive ability between mutant and control mice, careful consideration should be given to the genetic differences between the strains used as animal models and control animals [280]. Therefore, it is recommended that large sample sizes be used to compensate for genetic and epigenetic variability [281].
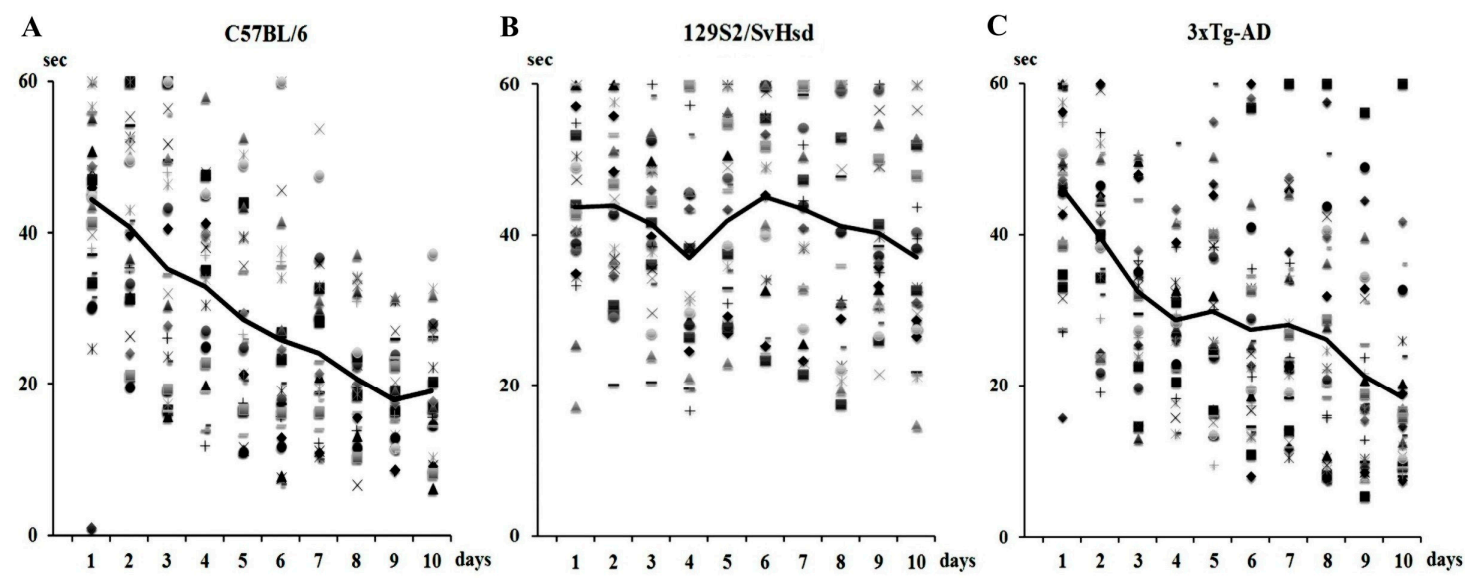

Figure 1. The latency in seconds to find a hidden platform within $60 \mathrm{~s}$ over 10 consecutive days of testing is presented for each group: C57BL/6 (A); 129S2/SvHsd (B); and the triple transgenic mouse model of Alzheimer's disease (AD) (3xTg-AD) (C). Latencies obtained from individual animals are plotted by different marks. Solid black lines show average latencies calculated for each day.
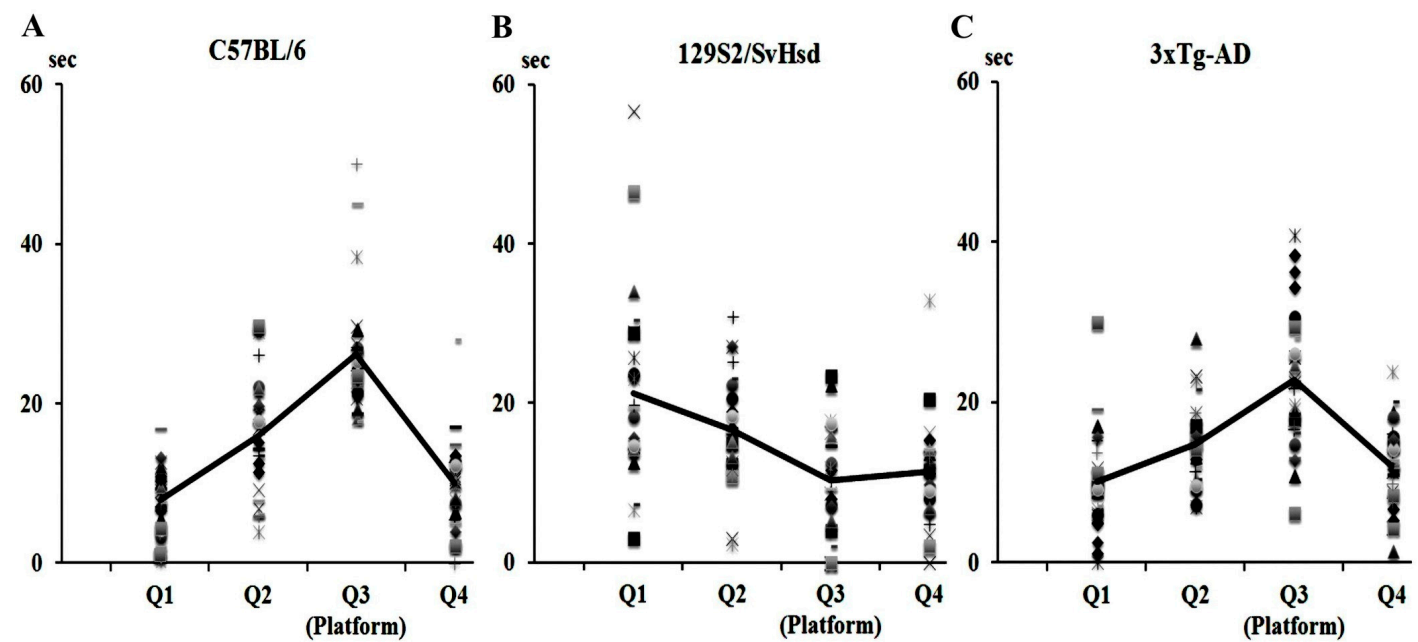

Figure 2. The total time (in seconds) spent in each quadrant (Q1, Q2, Q3, and Q4) during a 60-s probe trial (without the escape platform which was placed in Q3 during the 10-day training) is presented for the three strains of mice $(\mathbf{A}-\mathbf{C})$. Each individual animal's time is plotted by different marks. Solid black lines show the mean time spent in each quadrant. 


\subsection{Animal Model of Senescence}

An animal model of senescence, senescence accelerated mouse prone 8 (SAMP8), which is a non-genetically modified strain of mice with an accelerated aging process [282,283], displays amyloid plaques, Tau phosphorylation and oxidative stress $[284,285]$ as well as early onset senility and a shortened lifespan. In this animal model, transplantation of whole bone marrow into irradiated mice improved cognitive ability by normalizing proinflammatory cytokines and oxidative markers [286]. Their aging includes oxidative stress, chronic inflammation, calcium dyshomeostasis, chromosomal instability and nuclear and mitochondrial DNA damage [287].

\section{Stem Cells for Treating and Modeling AD}

Although tremendous efforts have been made to delay AD progression as well as ameliorate and cure $\mathrm{AD}$ symptoms, only four cholinesterase inhibitors (donepezil, galantamine, reivastigmine, and tacrine, which is rarely prescribed because of its associated side effects, especially liver damage) and an NMDAR antagonist (memantine) have been approved by the U.S. Food and Drug Administration for AD treatment. However, these drugs are not designed to halt or reverse the underlying process of $\mathrm{AD}$, but rather to compensate for declining brain function. Immunotherapy targeting amyloid or Tau has not been an ultimate solution for AD. In addition to SPs and NFTs, oxidative stress, mitochondrial dysfunction, hormone dysregulation, inflammation, mitotic dysfunction, calcium imbalance, and genetic risk factors are all involved in AD processes [9]. The disease is now recognized as multifactorial and consequently strongly demands more effective treatments. Recently, mounting evidence has shown that successful treatment of neurodegenerative diseases, including $\mathrm{AD}$, Parkinson's disease, and amyotrophic lateral sclerosis, can be achieved through the use of stem cells [288-294]. A search for the terms "Alzheimer's disease" and "Stem cells" yields more than 1000 articles in PubMed. Cell therapy may offer an opportunity to treat AD or delay its progression by being able to tackle several factors involved in its pathogenesis at once.

\subsection{Mesenchymal Stem Cells}

Mesenchymal stem cells (MSCs) are widely used for cell therapy because of their easy availability, their ready expansion in vitro, the lack of ethical constraints compared to those concerning embryonic stem cells, and their potential use as an autologous transplant that avoids graft rejection and/or side-effects associated with immunosuppression. MSCs can be isolated from a varied range of tissues, such as bone marrow (BM), umbilical cord blood (UCB), adipose tissue, placenta, etc. [295-297]. In brain disorders, drug delivery is required to go through the BBB; MSCs can cross the $\mathrm{BBB}$ and home in on areas of damage. When chemokine receptor type 4 (CXCR4), which reacts to the signaling factor stromal cell-derived factor-1 (SDF-1), is increased in MSCs, homing functions are accelerated for lesioned areas [298]. Although MSCs can migrate to inflammatory sites after intravenous injection, most of the transplanted MSCs might be trapped in the lung instead of reaching lesioned sites with inflammation [299]. In addition to intravascular delivery (vein and artery), different routes have been used to implant MSCs, including direct injection into damaged or lesioned tissue (e.g., intracerebral), intraventricular or intrathecal injection, as well as intranasal application [300,301].

Their paracrine effects, including the production of growth factors and anti-inflammatory cytokines and anti-apoptotic regulation, are strongly exerted and induce neural regeneration, remyelination and immunomodulation [302]. MSCs can reportedly reduce A $\beta$ levels by affecting amyloidogenesis and/or through microglia. Placenta-derived MSCs decreased the expression of APP and BACE1 and the activity of $\gamma$-secretase resulting in a significant reduction of $A \beta$ deposition and the improvement of cognitive function [303]. BM-MSCs can increase the population of activated microglia and reduce amyloid deposits through $A \beta$ clearance by phagocytosis [304]. However, microglia secrete high levels of proinflammatory cytokines in vitro, such as IL-1 $\beta$, TNF- $\alpha$, and 
IL-6, when stimulated with A $\beta$ [305]. The expression of IL-1 $\beta$ and TNF- $\alpha$ were significantly increased in 9-month-old APP /PS1 mice, but BM-MSC treatment markedly decreased the expression of both cytokines [306]. A $\beta$ toxicity was also reduced by increasing the expression of the anti-inflammatory cytokine IL-4 after MSC treatment. IL-4 is involved in the downregulation of TNF- $\alpha$ and the upregulation of IGF- 1 from microglia and also alters the phenotype of A $\beta$-committed microglia [307,308]. MSCs can produce prostaglandin E2, which modulates inflammatory reactions via the EP2 and EP4 receptors, and can reprogram macrophages to produce more IL-10 [309-311]. This anti-inflammatory cytokine, produced by monocytes and macrophages, seems to prevent the migration of neutrophils and reduce oxidative damage [312]. MSCs are likely to exert phagocytic effects on $A \beta$ as well as an anti-inflammatory influence on AD brains via microglia. However, the specific time point at which to apply MSCs needs to be clarified because the conditions in AD brains differ from one stage of AD to the next.

MSCs secrete neurotrophic factors such as vascular endothelial growth factor (VEGF), brain-derived neurotrophic factor (BDNF) and IGF-1 and foster the secretion of BDNF, nerve growth factor (NGF), VEGF and fibroblast growth factor (FGF) 2 in host brain tissues, which may induce endogenous neurogenesis, angiogenesis and neuronal protection [290,312]. Transplantation of MSCs into the subventricular zone (SVZ) or dentate gyrus (DG) has been shown to stimulate the proliferation, differentiation and maturation of endogenous neural stem cells (NSCs) toward a neuronal phenotype [313,314]. Intracerebrally or intravenously injected human adipose-derived MSCs drastically elevated endogenous neurogenesis as well as synaptic and dendritic stability [315]. MSCs transplanted into the lateral ventricle migrated into the hippocampus, including the DG, and enhanced hippocampal neurogenesis [316]. Thus, the interaction between grafted MSCs and endogenous NSCs is crucial for attenuating the neuronal damage and loss observed in AD. In addition, MSCs might be able to protect AD brains from glutamate excitatory-induced apoptosis by secreting growth factors, activating the PI3K/Akt pathway, increasing anti-apoptotic factors and reducing caspase-3 activity [317].

Inhibitory effects of MSCs on Tau pathology have been reported. The intrahippcampal implantation of MSCs significantly reduced hyperphosphorylated Tau, which was suggested to be due in part to a reduction of $A \beta_{42}$ levels [304]; the APP/PS1 mouse model was used for this study. Further studies are needed to elucidate the mechanisms underlying the inhibitory role of MSCs.

\subsection{Neural Stem Cells and Neurogenesis}

Adult neural stem cells (NSCs) are present in the SVZ of the lateral ventricle and the subgranular zone (SGZ) of the hippocampal DG. In the rodent SVZ, more than 30,000 neuroblasts migrate to the olfactory bulb through the rostral migratory stream each day, where they differentiate into granule and periglomerular neurons [318,319]. Young adult rats newly generate approximately 9000 cells in the SGZ every day (i.e., about $6 \%$ of total granule cells are generated in the DG each month), but most of these cells die between 1 and 2 weeks after birth [320]. Newly generated neurons from NSCs in the DG are restricted to the formation of mostly DG cells [321].

In aged rodents, the number of NSCs was reduced by $49 \%$ in the SVZ, but did not decrease in the SGZ [322]. In addition, Wnt-mediated signaling of astrocytes was reduced with age in the DG, leading to a downregulation of survivin (a mitotic regulator) expression in NSCs and resulting in the quiescence of NSCs in the aged brain [323] and a consequential age-related decline in neurogenesis [324]. NSCs obtained from aged brains are incapable of continuous proliferation and transdifferentiation into neurons because of their shorter telomeres and the lack of telomerase activity [325]. The existence of a quiescent stem cell population in the brain provides a therapeutic opportunity to restore damaged neurons following brain injury and disease.

NSCs are self-renewing and generate multiple neural lineages; after transplantation, NSCs can differentiate into neurons, astrocytes, and oligodendrocytes [326]. In APP knockout mice, transplanted NSCs cannot migrate or effectively differentiate into neurons in the cerebral cortex, 
since APP secretion from dying cells causes gliogenesis. A damaged APP system may jeopardize normal brain function, and its alteration may lead to excessive gliogenesis [327]. Once a hostile microenvironment is established in AD brains, transplanted NSCs are unlikely to differentiate into mature neurons without proper conditioning against the hostile niche [328]. Neural progenitor cells (NPCs) generated from the adult hippocampus predominantly differentiate into astrocytes, but NPCs transplanted with MSCs into hippocampal slice cultures favored oligodendrogenesis; the MSCs provide a pro-oligodendrogenic microenvironment for the transplanted NPCs [329]. Expression of the neuroprotective gene seladin-1 is decreased in NSCs of the AD brain. These cells are more predisposed to oxidative stress and cell death and might be protected by human BM-MSCs, in which high levels of seladin-1 have been found [328].

\subsection{Genetically Modified Cells}

Advancements in genetic technology enable the introduction or elimination of specific genes in stem cells. Genetically modified cells may have a powerful therapeutic potential to treat AD patients. Toll-like receptors (TLRs) play an important role in the activation of phagocytes/microglia in response to pathogens and damaged host cells in order to clear pathogens, damaged tissue and accumulated waste. Microglial activation by A $\beta$ requires TLR2, TLR4 and TLR6 [330]. CD14 acts as a co-receptor for TLR2 and TLR4, and is required for microglial phagocytosis of $A \beta$ [331]. Aside from TLR3, all TLRs use myeloid differentiation primary response protein 88 (MyD88) as an adaptor [332], which mediates pathogen recognition signaling in immune cells. A $\beta$ deposits are recognized by TLRs and induce inflammatory responses through the MyD88 signaling pathway, resulting in the exacerbation of $\beta$-amyloidosis [332]. BM cells genetically modified by deleting MyD88 increase the phagocytic activity of BM-derived macrophages and decrease brain inflammation [333].

NGF prevents neuronal death and improves spatial memory in animal models of aging [334]. However, it cannot be delivered into the CNS via peripheral administration due to its inability to cross the BBB because of its size and polarity [335]. In order to overcome this difficulty, genetically modified cells have been used to ameliorate side effects, including pain and weight loss, [336] and to protect basal forebrain cholinergic neurons. The results of a phase I trial suggested an improvement in cognitive decline [337]. The potential of NGF delivery via a viral vector is under study in an ongoing clinical trial [338].

BDNF is produced in the entorhinal cortex throughout life and is involved in neural plasticity [339]. The level of BDNF declines in the entorhinal cortex and the hippocampus in AD [340]. In 3xTg-AD mice treated with BDNF-secreting NSCs, hippocampal neural density increased and cognition improved without altering $A \beta$ or Tau pathology [326]. On the other hand, in the same transgenic mice, $A \beta$ plaques were reduced in the hippocampus by an intrahippocampal injection of genetically modified NSCs secreting the A $\beta$-degrading enzyme NEP, resulting in an increase of synaptic density. Non-genetically modified NSCs had no effect on the A $\beta$ plaques [341].

\section{4. iPS Cells as AD Models}

Since Yamanaka and his colleagues introduced induced pluripotent stem cells (iPS cells) in 2006 [342], a new area of stem cell research has been opened. The discovery of iPS cells made possible the development of different types of cellular models of degenerative diseases, including AD. The iPS cell-based AD models offer novel possibilities for deciphering the conundrum of senescent-related pathogenesis. Although they have been successfully generated from cells of a centenarian individual [343,344] and individuals with FAD [345] and SAD [346], they may reset the aging phenotype [347]. Telomere shortening is associated with increasing age to limit the proliferative capacity of stem cells [348]. The telomeres of iPS cells from old donors were elongated similarly as those from young donors [349]. Telomere length and function highly correlate with the pluripotency of iPS cells [350]. In iPS cells generated from the fibroblasts of FAD patients with mutations in PS1 (A246E) and PS2 (N141I), the ratio of $A \beta 42$ to $A \beta 40$ was significantly increased; this increased ratio 
was reversed by $\gamma$-secretase inhibitors [345]. In contrast, iPS cells generated from the fibroblasts of an individual with APP mutations and from the fibroblasts of SAD patients showed significantly high levels of A $\beta 40$, Tau phosphorylation at Thr 231 and active GSK-3 $\beta$, while the levels of phosphorylated Tau and active GSK-3 $\beta$ were reduced by $\beta$-secretase inhibitors, but not by $\gamma$-secretase inhibitors [346]. Although these iPS cell models of AD are useful in elucidating the molecular mechanisms of AD pathogenesis without the necessity of obtaining live neurons from AD patients, further studies are required to use iPS cells as a source for AD modeling and treatment.

\section{Conclusions}

The main challenges faced when developing AD treatment include a lack of good animal models that can fully replicate the disease process and symptoms, especially those seen in SAD, as well as a lack of good specific biomarkers to detect and trace AD progression. Current animal models of $\mathrm{AD}$ have been mainly generated from ADAD genes that facilitate the AD process. Therefore, the pathological changes and memory deficits typical of $\mathrm{AD}$ can be observed at a younger age. However, age is an important risk factor for AD, especially in late-onset $\mathrm{AD}$ (SAD), which is much more prevalent among $\mathrm{AD}$ patients than early-onset $\mathrm{AD}$. On the other hand, the formation and accumulation of $\mathrm{A} \beta$ and Tau, including their oligomers, as well as ER stress, $\mathrm{PrP}^{\mathrm{C}}, \mathrm{O}$-GlcNAcylation, oxidative stress, insulin/IGF resistance and glial malfunction are all involved in AD development, and all of them are directly and/or indirectly related to each other in AD pathogenesis and advancement, thereby creating a vicious cycle of $\mathrm{AD}$ progression in the brain. Senescence reinforces chronic inflammation including up-regulated TNF- $\alpha$, IL-1 $\beta$ and IL-6, while oxidative stress is characterized by increased ROS [351], which are also involved in AD pathogenesis [352]. Thus, there are multiple relationships between age-related and disease-related processes. The role of $A \beta$ and hyperphosphorylated Tau, which are both prominent in human AD brains at postmortem autopsy, should be understood in light of senescence-associated molecular mechanisms. Numerous signaling pathways are involved in causing amyloid plaques and hyperphosphorylated Tau. Therefore, to promote our understanding of $\mathrm{AD}$ pathogenesis, it might be helpful to consider the AD process in the following three ways: (1) if $\mathrm{AD}$ patients have some of the AD-linked genes, the disease will progress following the gene-specific signaling pathways; (2) if some of the metabolic changes advance independently from or without AD-linked genes, the disease will develop in accordance with dysregulated metabolism-dependent signaling pathways; and (3) if genetic factors and early metabolic failure are not involved, metabolic alteration will occur with aging and senescence-induced activation and/or impairment of signaling pathways, resulting in the development of AD. Genetic factors may foster this senescence-dependent AD progression.

Furthermore, a mono-therapeutic approach to AD is not a sufficient way to foster functional improvement in the brain and reverse disease development. AD could be treated according to the cause of the disease at an early stage, but once AD progresses, it would be difficult to interrupt the underlying vicious signaling circuits. Increased or decreased levels of AD-related ligands depend on age, the stage of $\mathrm{AD}$, and the brain region under observation (in which sensitivity to $\mathrm{A} \beta$ differs). The systemic application of a reagent targeted to a specific ligand or receptor may exert its effects equally on the ligand distributed throughout the whole brain, where levels of the targeted ligand vary as a result of age and the stage of the disease. Cell therapy can exert a multimodal effect on this multifactorial disease. The beneficial effects of paracrine mechanisms that reduce the overproduction of pro-inflammatory cytokines and induce immunomodulation and multilineage differentiation (or conditioned specific differentiation), which is also done by the transplanted cells themselves, are considered to be very useful for AD treatment. Transplanted cells have the capability to produce and secrete substances into the host tissue. These cells can also be engineered to deliver substances which, in part, activate a population of quiescent NSCs in the SGZ and SVZ, ameliorate the hostile niche created by the vicious cycle of $\mathrm{AD}$ and prevent cell apoptosis. Other combinatory therapeutic efforts may be required to correct the $\mathrm{AD}$ microenvironment in addition to cell therapy. We must 
wait for further evidence to answer these key questions: Which cell types are useful in treating or even preventing $\mathrm{AD}$, when is the optimal time period for starting cell therapy, which stages of $\mathrm{AD}$ are treatable, how many cells are needed, how often should the $\mathrm{AD}$ patient receive treatment, which routes of administration are most suitable for treatment, and so on. Nonetheless, to cut off the development of the vicious AD cycle, our efforts in hunting for the causative culprits of AD among a tangle of many factors must continue.

Supplementary Materials: Supplementary materials can be found at http://www.mdpi.com/1422-0067/16/ 11/25961/s1.

Acknowledgments: We thank Elisa Brann and James Dutt for their English corrections of the manuscript. This work was supported by the grants GACR P304/12/G069 and GACR P304/11/0184.

Author Contributions: Takashi Amemori wrote the manuscript. Pavla Jendelova and Eva Sykova revised the manuscript. Jiri Ruzicka and Lucie Machova Urdzikova performed the behavioral testing.

Conflicts of Interest: The authors declare no conflict of interest.

\section{References}

1. O'Brien, C. Auguste D. and Alzheimer's disease. Science 1996, 273, 28. [CrossRef] [PubMed]

2. Gouras, G.K.; Almeida, C.G.; Takahashi, R.H. Intraneuronal A $\beta$ accumulation and origin of plaques in Alzheimer's disease. Neurobiol. Aging 2005, 26, 1235-1244. [CrossRef] [PubMed]

3. Goedert, M. Oskar Fischer and the study of dementia. Brain 2009, 132, 1102-1111. [CrossRef] [PubMed]

4. Maurer, K.; Volk, S.; Gerbaldo, H. Augaste D and Alzheimer's disease. Lancet 1997, 349, 1546-1549. [CrossRef]

5. Graeber, M.B.; Kosel, S.; Egensperger, R.; Banati, R.B.; Muller, U.; Bise, K.; Hoff, P.; Moller, H.J.; Fujisawa, K.; Mehraein, P. Rediscovery of the case described by Alois Alzheimer in 1911: Historical, histological and molecular genetic analysis. Neurogenetics 1997, 1, 73-80. [CrossRef] [PubMed]

6. Graeber, M.B.; Kosel, S.; Grasbon-Frodl, E.; Moller, H.J.; Mehraein, P. Histopathology and APOE genotype of the first Alzheimer disease patient, Auguste D. Neurogenetics 1998, 1, 223-228. [CrossRef] [PubMed]

7. Muller, U.; Winter, P.; Graeber, M.B. A presenilin 1 mutation in the first case of Alzheimer's disease. Lancet Neurol. 2013, 12, 129-130. [CrossRef]

8. Rupp, C.; Beyreuther, K.; Maurer, K.; Kins, S. A presenilin 1 mutation in the first case of Alzheimer's disease: Revised. Alzheimers Dement. 2014, 10, 869-872. [CrossRef] [PubMed]

9. Anand, R.; Gill, K.D.; Mahdi, A.A. Therapeutics of Alzheimer's disease: Past, present and future. Neuropharmacology 2014, 76, 27-50. [CrossRef] [PubMed]

10. Imtiaz, B.; Tolppanen, A.M.; Kivipelto, M.; Soininen, H. Future direction in Alzheimer's disease from risk factors to prevention. Biochem. Pharmacol. 2014, 88, 661-670. [CrossRef] [PubMed]

11. Cacquevel, M.; Aeschbach, L.; Houacine, J.; Fraering, P.C. Alzheimer's disease-linked mutations in presenilin-1 result in a drastic loss of activity in purified $\gamma$-secretase complexes. PLoS ONE 2012, 7, e35133. [CrossRef] [PubMed]

12. Bateman, R.J.; Aisen, P.S.; de Strooper, B.; Fox, N.C.; Lemere, C.A.; Ringman, J.M.; Salloway, S.; Sperling, R.A.; Windisch, M.; Xiong, C. Autosonal-dominant Alzheimer's disease: A review and proposal for the prevention of Alzheimer's disease. Alzheimers Res. Ther. 2011, 3, 1. [CrossRef] [PubMed]

13. Citron, M.; Westaway, D.; Xia, W.; Carlson, G.; Diehl, T.; Levesque, G.; Johnson-Wood, K.; Lee, M.; Seubert, P.; Davis, A.; et al. Mutant presenilins of Alzheimer's disease increase production of 42-residue amyloid $\beta$-protein in both transfected cells and transgenic mice. Nat. Med. 1997, 3, 67-72. [CrossRef] [PubMed]

14. Selkoe, D.J. Alzheimer's disease: Genes, proteins, and therapy. Physiol. Rev. 2001, 81, 741-766. [CrossRef] [PubMed]

15. Selfridge, J.E.; Lezi, E.; Lu, J.; Swerdlow, R.H. Role of mitochondrial homeostasis and dynamics in Alzheimer's disease. Neurobiol. Dis. 2013, 51, 3-12. [CrossRef] [PubMed]

16. Mahley, R.W.; Nathan, B.P.; Pitas, R.E. Apolipoprotein E. Structure, function, and possible roles in Alzheimer's disease. Ann. N. Y. Acad. Sci. 1996, 777, 139-145. [CrossRef] [PubMed]

17. Mahley, R.W.; Rall, S.C., Jr. Apolipoprotein E: Far more than a lipid transport protein. Annu. Rev. Genom. Hum. Genet. 2000, 1, 507-537. [CrossRef] [PubMed]

18. Beffert, U.; Stolt, P.C.; Herz, J. Functions of lipoprotein receptors in neurons. J. Lipid Res. 2004, 45, 403-409. [CrossRef] [PubMed] 
19. Cedazo-Minguez, A. Apolipoprotein E and Alzheimer's disease: Molecular mechanisms and therapeutic opportunities. J. Cell. Mol. Med. 2007, 11, 1227-1238. [CrossRef] [PubMed]

20. Roses, A.D. Apolipoprotein E alleles as risk factors in Alzheimer's disease. Annu. Rev. Med. 1996, 47, 387-400. [CrossRef] [PubMed]

21. Bertram, L.; Tanzi, R.E. The genetics of Alzheimer's disease. Prog. Mol. Biol. Transl. Sci. 2012, 107, 79-100. [PubMed]

22. Slooter, A.J.; Cruts, M.; Kalmijn, S.; Hofman, A.; Breteler, M.M.; van Broeckhoven, C.; van Duijn, C.M. Risk estimates of dementia by apolipoprotein E genotypes from a population-based incidence study: The Rotterdam study. Arch. Neurol. 1988, 55, 964-968. [CrossRef]

23. Hollingworth, P.; Harold, D.; Sims, R.; Gerrish, A.; Lambert, J.C.; Carrasquillo, M.M.; Abraham, R.; Hamshere, M.L.; Pahwa, J.S.; Moskvina, V.; et al. Common variants at ABCA7, MS4A6A/MS4A4E, EPHA1, CD33 and CD2AP are associated with Alzheimer's disease. Nat. Genet. 2011, 43, 429-435. [CrossRef] [PubMed]

24. Naj, A.C.; Jun, G.; Beecham, G.W.; Wang, L.S.; Vardarajan, B.N.; Buros, J.; Gallins, P.J.; Buxbaum, J.D.; Jarvik, G.P.; Crane, P.K.; et al. Common variants at MS4A4/MS4A6E, CD2AP, CD33 and EPHA1 are associated with late-onset Alzheimer's disease. Nat. Genet. 2011, 43, 436-441. [CrossRef] [PubMed]

25. Lambert, J.C.; Ibrahim-Verbaas, C.A.; Harold, D.; Naj, A.C.; Sims, R.; Bellenguez, C.; Jun, G.; Destefano, A.L.; Bis, J.C.; Beecham, G.W.; et al. Meta-analysis of 74,046 individuals identifies 11 new susceptibility loci for Alzheimer's disease. Nat. Genet. 2013, 45, 1452-1458. [CrossRef] [PubMed]

26. Gandhi, S.; Wood, N.W. Genome-wide association studies: The key to unlocking neurodegeneration? Nat. Neurosci. 2010, 13, 789-794. [CrossRef] [PubMed]

27. Harold, D.; Abraham, R.; Haooingworth, P.; Sims, R.; Gerrish, A.; Hamshere, M.L.; Pahwa, J.S.; Moskvina, V.; Dowzell, K.; Williams, A.; et al. Genome-wide association study identifies variants at CLU and PICALM associated with Alzheimer's disease. Nat. Genet. 2009, 41, 1088-1093. [CrossRef] [PubMed]

28. Lambert, J.C.; Heath, S.; Even, G.; Campion, D.; Sleegers, K.; Hiltunen, M.; Combarros, O.; Zelenika, D.; Bullido, M.J.; Teavernier, B.; et al. Genome-wide association study identifies variants at CLU and CR1 associated with Alzheimer's disease. Nat. Genet. 2009, 41, 1094-1099. [CrossRef] [PubMed]

29. Chapuis, J.; Hansmannel, F.; Gistelinck, M.; Mounier, A.; van Cauwenberghe, C.; Kolen, K.V.; Geller, F.; Sottejeau, Y.; Harold, D.; Dourlen, P.; et al. Increased expression of BIN1 mediates Alzheimer genetic risk by modulating Tau pathology. Mol. Psychiatry 2013, 18, 1225-1234. [CrossRef] [PubMed]

30. Antúnez, C.; Boada, M.; González-Pérez, A.; Gayán, J.; Ramírez-Lorca, R.; Marín, J.; Hernández, I.; Moreno-Rey, C.; Morón, F.J.; López-Arrieta, J.; et al. The membrane-spanning 4-domains, subfamily A (MS4A) gene cluster contains a common variant associated with Alzheimer's disease. Genome Med. 2011, 3, 33. [CrossRef] [PubMed]

31. Bradshaw, E.M.; Chibnik, L.B.; Keenan, B.T.; Ottoboni, L.; Raj, T.; Tang, A.; Rosenkrantz, L.L.; Imboywa, S.; Lee, M.; von Korff, A.; et al. CD33 Alzheimer's disease locus: Altered monocyte function and amyloid biology. Nat. Neurosci. 2013, 16, 848-850. [CrossRef] [PubMed]

32. Griciuc, A.; Serrano-Pozo, A.; Parrado, A.R.; Lesinski, A.N.; Asselin, C.N.; Mullin, K.; Hooli, B.; Choi, S.H.; Hyman, B.T.; Tanzi, R.E. Alzheimer's disease risk gene CD33 inhibits microglial uptake of amyloid $\beta$. Neuron 2013, 78, 631-643. [CrossRef] [PubMed]

33. Karch, C.M.; Jeng, A.T.; Nowotny, P.; Cady, J.; Cruchaga, C.; Goate, A.M. Expression of novel Alzheimer's disease risk genes in control and Alzheimer's disease brains. PLoS ONE 2012, 7, e50976. [CrossRef] [PubMed]

34. Guerreiro, R.; Wojtas, A.; Bras, J.; Carrsquillo, M.; Rogaeva, E.; Majounie, E.; Cruchaga, C.; Sassi, C.; Kauwe, J.S.; Younkin, S.; et al. TREM2 variants in Alzheimer's disease. N. Engl. J. Med. 2013, 368, 117-127. [CrossRef] [PubMed]

35. Jonsson, T.; Stefansson, H.; Steinberg, S.; Jonsdottir, I.; Jonsson, P.V.; Snaedal, J.; Bjornsson, S.; Huttenlocher, J.; Levey, A.I.; Lah, J.J.; et al. Variant of TREM2 associated with the risk of Alzheimer's disease. N. Engl. J. Med. 2013, 368, 107-116. [CrossRef] [PubMed]

36. Rogaeva, E.; Meng, Y.; Lee, J.H.; Gu, Y.; Kawarai, T.; Zou, F.; Katayama, T.; Baldwin, C.T.; Cheng, R.; Hasegawa, H.; et al. The neuronal sortilin-related SORL1 is genetically associated with Alzheimer disease. Nat. Genet. 2007, 39, 168-177. [CrossRef] [PubMed]

37. Miyashita, A.; Koike, A.; Jun, G.; Wang, L.S.; Takahashi, S.; Matsubara, E.; Kawarabayashi, T.; Shoji, M.; Tomita, N.; Arai, H.; et al. SORL1 is genetically associated with late-onset Alzheimer's disease in Japanese, Koreans and Caucasians. PLoS ONE 2013, 8, e58618. [CrossRef] [PubMed] 
38. Jones, L.; Holmans, P.A.; Hamshere, M.L.; Harold, D.; Moskvina, V.; Ivanov, D.; Pocklington, A.; Abraham, R.; Hollingworth, P.; Sims, R.; et al. Genetic evidence implicates the immune system and cholesterol metabolism in the aetiology of Alzheimer's disease. PLoS ONE 2010, 5, e13950. [CrossRef] [PubMed]

39. De Strooper, B. Proteases and proteolysis in Alzheimer disease: A multifactorial view on the disease process. Physiol. Rev. 2010, 90, 465-494. [CrossRef] [PubMed]

40. Santos, C.R.A.; Cardoso, I.; Goncalves, I. Key enzymes and proteins in amyloid- $\beta$ production and clearance. In Alzheimer's Disease Pathogenesis - Core Concepts, Shifting Paradigms and Therapeutic Targets; de la Monte, S., Ed.; InTech: Shanghai, China, 2011; pp. 53-86.

41. Nikolaev, A.; McLaughlin, T.; O'Leary, D.D.; Tessier-Lavigne, M. APP binds DR6 to trigger axon pruning and neuron death via distinct caspases. Nature 2009, 457, 981-989. [CrossRef] [PubMed]

42. Hardy, J.; Allsop, D. Amyloid deposition as the central event in the aetiology of Alzheimer's disease. Trends Pharmacol. Sci. 1991, 12, 383-388. [CrossRef]

43. Selkoe, D.J. The molecular pathology of Alzheimer's disease. Neuron 1991, 6, 487-498. [CrossRef]

44. Hardy, J.A. Higgins, G.A. Alzheimer's disease: The amyloid cascade hypothesis. Science 1992, 256, $184-185$. [CrossRef] [PubMed]

45. Hardy, J.; Selkoe, D.J. The amyloid hypothesis of Alzheimer's disease: Progress and problems on the road to therapeutics. Science 2002, 297, 353-356. [CrossRef] [PubMed]

46. Giannakopoulos, P.; Herrmann, F.R.; Bussiere, T.; Bouras, C.; Kovari, E.; Perl, D.P.; Mossison, J.H.; Gold, G.; Hof, P.R. Tangle and neuron numbers, but not amyloid load, predict cognitive status in Alzheimer's disease. Neurology 2003, 60, 1495-1500. [CrossRef] [PubMed]

47. Naslund, J.; Haroutunian, V.; Mohs, R.; Davis, K.L.; Davies, P.; Greengard, P.; Buxbaum, J.D. Correlation between elevated levels of amyloid $\beta$-peptide in the brain and cognitive decline. JAMA 2000, 283, 1571-1577. [CrossRef] [PubMed]

48. McLean, C.A.; Cherny, R.A.; Fraser, F.W.; Fuller, S.J.; Smith, M.J.; Beyreuther, K.; Bush, A.I.; Master, C.L. Soluble pool of $A \beta$ amyloid as a determinant of severity of neurodegeneration in Alzheimer's disease. Ann. Neurol. 1999, 46, 860-866. [CrossRef]

49. Walsh, D.M.; Klyubin, I.; Fadeeva, J.V.; Cullen, W.K.; Anwyl, R.; Wolfe, M.S.; Rowan, M.J.; Selkoe, D.J. Naturally secreted oligomers of amyloid $\beta$ protein potently inhibit hippocampal long-term potentiation in vivo. Nature 2002, 416, 535-539. [CrossRef] [PubMed]

50. Cleary, J.P.; Walsh, D.M.; Hofmeister, J.J.; Schankar, G.M.; Kukskowski, M.A.; Selkoe, D.J.; Ashe, K.H. Natural oligomers of the amyloid- $\beta$ protein specifically disrupt cognitive function. Nat. Neurosci. 2005, 8, 79-84. [CrossRef] [PubMed]

51. Bitan, G.; Fradinger, E.A.; Spring, S.M.; Teplow, D.B. Neurotoxic protein oligomers-What you see is not always what you get. Amyloid 2005, 12, 88-95. [CrossRef] [PubMed]

52. Zhao, W.Q.; de Felice, F.G.; Fernandez, S.; Chen, H.; Lambert, M.P.; Quon, M.J.; Krafft, G.A.; Klein, W.L. Amyloid $\beta$ oligomers induce impairment of neuronal insulin receptors. FASEB J. 2008, 22, 246-560. [CrossRef] [PubMed]

53. Zhao, W.Q. Alkon, D.L. Role of insulin and insulin receptor in learning and memory. Mol. Cell. Endocrinol. 2001, 177, 125-134. [CrossRef]

54. Barry, A.E.; Klyubin, I.; McDonald, J.M.; Mably, A.J.; Farrell, M.A.; Scott, M.; Walsh, D.M.; Rowan, M.J. Alzheimer's disease brain-derived amyloid- $\beta$-mediated inhibition of LTP in vivo is prevented by immunotargeting cellular prion protein. J. Neurosci. 2011, 31, 7259-7263. [CrossRef] [PubMed]

55. Um, J.W.; Nygaard, H.B.; Heiss, J.K.; Kostylev, M.A.; Stagi, M.; Vortmeyer, A.; Wisniewski, T.; Gunther, E.C.; Strittmatter, S.M. Alzheimer amyloid- $\beta$ oligomer bound to postsynaptic prion protein activates Fyn to impair neurons. Nat. Neurosci. 2012, 15, 1227-1235. [CrossRef] [PubMed]

56. Jin, M.; Shepardson, N.; Yang, T.; Chen, G.; Walsh, D.; Selkoe, D.J. Soluble amyloid $\beta$-protein dimers isolated from Alzheimer cortex directly induce Tau hyperphosphorylation and neuritic degeneration. Proc. Natl. Acad. Sci. USA 2011, 108, 5819-5824. [CrossRef] [PubMed]

57. Kayed, R.; Lasagna-Reeves, C.A. Molecular mechanisms of amyloid oligomers toxicity. J. Alzheimers Dis. 2013, 33, S67-S78. [PubMed]

58. Pei, J.J.; Hugon, J. mTOR-dependent signalling in Alzheimer's disease. J. Cell. Mol. Med. 2008, 12, 2525-2532. [CrossRef] [PubMed] 
59. Foster, J.K.; Verdile, G.; Bates, K.A.; Martins, R.N. Immunization in Alzheimer's disease: Naive hope or realistic clinical potential? Mol. Psychiatry 2009, 14, 239-251. [CrossRef] [PubMed]

60. Farlow, M.; Arnold, S.E.; van Dyck, C.H.; Aisen, P.S.; Snider, B.J.; Porsteinsson, A.P.; Friedrich, S.; Dean, R.A.; Gonzales, C.; Sethuraman, G.; et al. Safety and biomarker effects of solanezumab in patients with Alzheimer's disease. Alzheimers Dement. 2012, 8, 261-271. [CrossRef] [PubMed]

61. Goure, W.F.; Krafft, G.A.; Jerecic, J.; Hefti, F. Targeting the proper amyloid- $\beta$ neuronal toxins: A path forward for Alzheimer's disease immunotherapeutics. Alzheimers Res. Ther. 2014, 6, 42. [CrossRef] [PubMed]

62. Doody, R.S.; Thomas, R.G.; Farlow, M.; Iwatsubo, T.; Vellas, B.; Joffe, S.; Kieburtz, K.; Raman, R.; Sun, X.; Aisen, P.S.; et al. Alzheimer's Disease Cooperative Study Steering Committee, Solanezumab Study Group. Phase 3 trials of solanezumab for mild-to-moderate Alzheimer's disease. N. Engl. J. Med. 2014, 370, 311-321. [CrossRef] [PubMed]

63. Siemers, E.R.; Sundell, K.L.; Carlson, C.; Case, M.; Sethuraman, G.; Liu-Seifert, H.; Dowsett, S.A.; Pontecorvo, M.J.; Dean, R.A.; Demattos, R. Phase 3 solanezumab trials: Secondary outcomes in mild Alzheimer's disease patients. Alzheimers Dement. 2015. [CrossRef] [PubMed]

64. Wisniewski, T.; Goni, F. Immunotherapy for Alzheimer's disease. Biochem. Pharmacol. 2014, 88, 499-507. [CrossRef] [PubMed]

65. Carrillo, M.C.; Brashear, H.R.; Logovinsky, V.; Ryan, J.M.; Feldman, H.H.; Siemers, E.R.; Abushakra, S.; Hartley, D.M.; Petersen, R.C.; Khachaturian, A.S.; et al. Can we prevent Alzheimer's disease? Secondary "prevention" trials in Alzheimer's disease. Alzheimers Dement. 2013, 9, 123-131. [CrossRef] [PubMed]

66. Lindwall, G.; Cole, R.D. Phosphorylation affects the ability of Tau protein to promote microtubule assembly. J. Biol. Chem. 1984, 259, 5301-5305. [PubMed]

67. Caceres, A.; Kosik, K.S. Inhibition of neurite polarity by Tau antisense oligonucleotides in primary cerebellar neurons. Nature 1990, 343, 461-463. [CrossRef] [PubMed]

68. Lee, V.M.; Goedert, M.; Trojanowski, J.Q. Neurodegenerative tauopathies. Annu. Rev. Neurosci. 2001, 24, 1121-1159. [CrossRef] [PubMed]

69. Hong, M.; Zhukareva, V.; Vogelsberg-Ragaglia, V.; Wszolek, Z.; Reed, L.; Miller, B.I.; Geschwind, D.H.; Bird, T.D.; McKeel, D.; Goate, A.; et al. Mutation-specific functional impairments in distinct Tau isoforms of hereditary FTDP-17. Science 1998, 282, 1914-1917. [CrossRef] [PubMed]

70. Garcia, M.L.; Cleveland, D.W. Going new places using an old MAP: Tau, microtubules and human neurodegenerative disease. Curr. Opin. Cell Biol. 2001, 13, 41-48. [CrossRef]

71. Gomez-Isla, T.; Hollister, R.; West, H.; Mui, S.; Growdon, J.H.; Petersen, R.C.; Parisi, J.E.; Hyman, B.T. Neuronal loss correlates with but exceeds neurofibrillary tangles in Alzheimer's disease. Ann. Neurol. 1997, 41, 17-24. [CrossRef] [PubMed]

72. Lasagna-Reeves, C.A.; Castillo-Carranza, D.L.; Sengupta, U.; Guerrero-Munoz, M.J.; Kiritoshi, T.; Neugebauer, V.; Jackson, G.R.; Kayed, R. Alzheimer brain-derived Tau oligomers propagate pathology from endogenous Tau. Sci. Rep. 2012, 2, 700. [CrossRef] [PubMed]

73. Berger, Z.; Roder, H.; Hanna, A.; Carlson, A.; Rangachari, V.; Yue, M.; Wszolek, Z.; Ashe, K.; Knight, J.; Dickson, D.; et al. Accumulation of pathological Tau species and memory loss in a conditional model of tauopathy. J. Neurosci. 2007, 27, 3650-3662. [CrossRef] [PubMed]

74. Ballatore, C.; Lee, V.M.; Trojanowski, J.Q. Tau-mediated neurodegeneration in Alzheimer's disease and related disorders. Nat. Rev. Neurosci. 2007, 8, 663-672. [CrossRef] [PubMed]

75. Yoshiyama, Y.; Higuchi, M.; Zhang, B.; Huang, S.M.; Iwata, N.; Saido, T.C.; Maeda, J.; Suhara, T.; Trojanowski, J.Q.; Lee, V.M. Synapse loss and microglial activation precede tangles in a P301S tauopathy mouse model. Neuron 2007, 53, 337-351. [CrossRef] [PubMed]

76. Sergeant, N.; Delacourte, A.; Buee, L. Tau protein as a differential biomarker of tauopathies. Biochim. Biophys. Acta 2005, 1739, 179-197. [CrossRef] [PubMed]

77. Wilhelmsen, K.C.; Lynch, T.; Pavlou, E.; Higgins, M.; Nygaard, T.G. Localization of disinhibitiondementia-parkinsonism-amyotrophy complex to 17q2-22. Am. J. Hum. Genet. 1994, 55, 1159-1165. [PubMed]

78. Goedert, M. Tau gene mutations and their effects. Mov. Disord. 2005, 12, 45-52. [CrossRef] [PubMed]

79. Small, S.A.; Duff, K. Linking A $\beta$ and Tau in late-onset Alzheimer's disease: A dual pathway hypothesis. Neuron 2008, 60, 534-542. [CrossRef] [PubMed]

80. Castellani, R.J.; Perry, G. The complexities of the pathology-pathogenesis relationship in Alzheimer disease. Biochem. Pharmacol. 2014, 88, 671-676. [CrossRef] [PubMed] 
81. Holmes, C.; Boche, D.; Wilkinson, D.; Yadegarfar, G.; Hopkins, V.; Bayer, A.; Jones, R.W.; Bullock, R.; Love, S.; Neal, J.W.; et al. Long-term effects of A $\beta 42$ immunisation in Alzheimer's disease: Follow-up of a randomised, placebo-controlled phase I trial. Lancet 2008, 372, 216-223. [CrossRef]

82. Rosenmann, H.; Grigoriadis, N.; Karussis, D.; Boimel, M.; Touloumi, O.; Ovadia, H.; Abramsky, O. Tauopathy-like abnormalities and neurologic deficits in mice immunized with neuronal Tau protein. Arch. Neurol. 2006, 63, 1459-1467. [CrossRef] [PubMed]

83. Boutajangout, A.; Ingadottir, J.; Davies, P.; Sigurdsson, E.M. Passive immunization targeting pathological phospho-Tau protein in a mouse model reduces functional decline and clears Tau aggregates from the brain. J. Neurochem. 2011, 118, 658-667. [CrossRef] [PubMed]

84. Chai, X.; Wu, S.; Murray, T.K.; Kinley, R.; Cella, C.V.; Sims, H.; Buckner, N.; Hanmer, J.; Davies, P.; O'Neill, M.J.; et al. Passive immunization with anti-Tau antibodies in two transgenic models: Reduction of Tau pathology and delay of disease progression. J. Biol. Chem. 2011, 286, 34457-34467. [CrossRef] [PubMed]

85. Morley, J.E.; Farr, S.A. The role of amyloid- $\beta$ in the regulation of memory. Biochem. Pharmacol. 2014, 88, 479-485. [CrossRef] [PubMed]

86. Muller, U.C.; Zheng, H. Physiological functions of APP family proteins. Cold Spring Harb. Perspect. Med. 2012, 2. [CrossRef] [PubMed]

87. Ke, Y.D.; Suchowerska, A.K.; van der Hoven, J.; de Silva, D.M.; Wu, C.W.; van Eersel, J.; Ittner, A.; Ittner, L.M. Lessons from Tau-deficient mice. Int. J. Alzheimers Dis. 2012, 2012. [CrossRef] [PubMed]

88. Taylor, R.C.; Dillin, A. Aging as an event of proteostasis collapse. Cold Spring Harb. Perspect. Biol. $2011,3$. [CrossRef] [PubMed]

89. Schroder, M.; Kaufman, R.J. The mammalian unfolded protein response. Annu. Rev. Biochem. 2005, 74, 739-789. [CrossRef] [PubMed]

90. Urra, H.; Dufey, E.; Lisbona, F.; Rojas-Rivera, D.; Hetz, C. When ER stress reaches a dead end. Biochim. Biophys. Acta 2013, 1833, 3507-3517. [CrossRef] [PubMed]

91. Salminen, A.; Kauppinen, A.; Suuronen, T.; Kaarniranta, K.; Ojala, J. ER stress in Alzheimer's disease: A novel neuronal trigger for inflammation and Alzheimer's pathology. J. Neuroinflamm. 2009, 6, 41. [CrossRef] [PubMed]

92. Li, G.; Mongillo, M.; Chin, K.T.; Harding, H.; Ron, D.; Marks, A.R.; Tabas, I. Role of ERO1- $\alpha$-mediated stimulation of inositol 1,4,5-tirphoate receptor activity in endoplasmic reticulum stress-induced apoptosis. J. Cell Biol. 2009, 186, 783-792. [CrossRef] [PubMed]

93. Urano, F.; Wang, X.; Bertolotti, A.; Zhang, Y.; Chung, P.; Harding, H.P.; Ron, D. Coupling of stress in the ER to activation of JNK protein kinases by transmembrane protein kinase IRE1. Science 2000, 287, 664-666. [CrossRef] [PubMed]

94. Sekine, Y.; Takeda, K.; Ichijo, H. The ASK1-MAP kinase signaling in ER stress and neurodegenerative diseases. Curr. Mol. Med. 2006, 6, 87-97. [CrossRef] [PubMed]

95. Kelleher, I.; Garwood, C.; Hanger, D.P.; Anderton, B.H.; Noble, W. Kinase activities increase during the development of tauopathy in htau mice. J. Neurochem. 2007, 103, 2256-2267. [CrossRef] [PubMed]

96. Ploia, C.; Antoniou, X.; Sclip, A.; Grande, V.; Cardinetti, D.; Colombo, A.; Canu, N.; Benussi, L.; Ghidoni, R.; Forloni, G.; et al. JNK plays a key role in Tau hyperphosphorylation in Alzheimer's disease models. J. Alzheimers Dis. 2011, 26, 315-329. [PubMed]

97. Cuanalo-Contreras, K.; Mukherjee, A.; Soto, C. Role of protein misfolding and proteostasis deficiency in protein misfolding diseases and aging. Int. J. Cell Biol. 2013, 2013. [CrossRef] [PubMed]

98. Vallabhapurapu, S.; Karin, M. Regulation and function of NF-kappaB transcription factors in the immune system. Annu. Rev. Immunol. 2009, 27, 693-733. [CrossRef] [PubMed]

99. Rossner, S.; Sastre, M.; Bourne, K.; Lichtenthaler, S.F. Transcriptional and translational regulation of BACE1 expression-Implications for Alzheimer's disease. Prog. Neurobiol. 2006, 79, 95-111. [CrossRef] [PubMed]

100. Resende, R.; Moreira, P.I.; Proenca, T.; Deshpande, A.; Busciglio, J.; Pereira, C.; Oliveira, C.R. Brain oxidative stress in a triple-transgenic mouse model of Alzheimer disease. Free Radic. Biol. Med. 2008, 44, 2051-2057. [CrossRef] [PubMed]

101. Morawe, T.; Hiebel, C.; Kern, A.; Behl, C. Protein homeostasis, aging and Alzheimer's disease. Mol. Neurobiol. 2012, 46, 41-54. [CrossRef] [PubMed] 
102. Huang, Y.; Mucke, L. Alzheimer mechanisms and therapeutic strategies. Cell 2012, 148, $1204-1222$. [CrossRef] [PubMed]

103. Kakimura, J.; Kitamura, Y.; Takata, K.; Umeki, M.; Suzuki, S.; Shibagaki, K.; Taniguchi, T.; Nomura, Y.; Gebicke-Haerter, P.J.; Smith, M.A.; et al. Microglial activation and amyloid- $\beta$ clearance induced by exogenous heat-shock proteins. FASEB J. 2002, 16, 601-603. [CrossRef] [PubMed]

104. Koren, J., III; Jinwal, U.K.; Lee, D.C.; Jones, J.R.; Shults, C.L.; Johnson, A.G.; Anderson, L.J.; Dickey, C.A. Chaperone signalling complexes in Alzheimer's disease. J. Cell. Mol. Med. 2009, 13, 619-630. [CrossRef] [PubMed]

105. Wilhelmus, M.M.; de Waal, R.M.; Verbeek, M.M. Heat shock proteins and amateur chaperones in amyloid- $\beta$ accumulation and clearance in Alzheimer's disease. Mol. Neurobiol. 2007, 35, 203-216. [CrossRef] [PubMed]

106. Jinwal, U.K.; O’Leary, J.C., III; Borysov, S.I.; Jones, J.R.; Li, Q.; Koren, J., III; Abisambra, J.F.; Vestal, G.D.; Lawson, L.Y.; Johnson, A.G.; et al. Hsc70 rapidly engages Tau after microtubule destabilization. J. Biol. Chem. 2010, 285, 16798-16805. [CrossRef] [PubMed]

107. Sahara, N.; Murayama, M.; Mizoroki, T.; Urushitani, M.; Imai, Y.; Takahashi, R.; Murata, S.; Tanaka, K.; Takashima, A. In vivo evidence of CHIP up-regulation attenuating Tau aggregation. J. Neurochem. 2005, 94, 1254-1263. [CrossRef] [PubMed]

108. Dickey, C.A.; Koren, J.; Zhang, Y.J.; Xu, Y.F.; Jinwal, U.K.; Birnbaum, M.J.; Monks, B.; Sun, M.; Cheng, J.Q.; Patterson, C.; et al. Akt and CHIP coregulate Tau degradation through coordinated interactions. Proc. Natl. Acad. Sci. USA 2008, 105, 3622-3627. [CrossRef] [PubMed]

109. Martin, M.; Dotti, C.G.; Ledesma, M.D. Brain cholesterol in normal and pathological aging. Biochim. Biophys. Acta 2010, 1801, 934-944. [CrossRef] [PubMed]

110. Wang, H.; Eckel, R.H. What are lipoproteins doing in the brain? Trends Endocrinol. Metab. 2014, $25,8-14$. [CrossRef] [PubMed]

111. Wood, W.G.; Schroeder, F.; Igbavboa, U.; Avdulov, N.A.; Chochina, S.V. Brain membrane cholesterol domains, aging and amyloid $\beta$-peptides. Neurobiol. Aging 2002, 23, 685-694. [CrossRef]

112. Ariga, T.; Wakade, C.; Yu, R.K. The pathological roles of ganglioside metabolism in Alzheimer's disease: Effects of gangliosides on neurogenesis. Int. J. Alzheimers Dis. 2011, 2011, 193618. [CrossRef] [PubMed]

113. Kakio, A.; Nishimoto, S.I.; Yanagisawa, K.; Kazutsumi, Y.; Matsuzaki, K. Cholesterol-dependent formation on GM1 ganglioside-bound amyloid $\beta$-protein, an endogenous seed for Alzheimer amyloid. J. Biol. Chem. 2001, 276, 24985-24990. [CrossRef] [PubMed]

114. Fantini, J.; Yahi, N.; Garmy, N. Cholesterol accelerates the binding of Alzheimer's $\beta$-amyloid peptide to ganglioside GM1 through a universal hydrogen-bond-dependent sterol tuning of glycolipid conformation. Front. Physiol. 2013, 4, 120. [CrossRef] [PubMed]

115. Yuyama, K.; Yanagisawa, K. Sphingomyelin accumulation provides a favorable milieu for GM1 ganglioside-induced assembly of amyloid $\beta$-protein. Neurosci. Lett. 2010, 481, 168-172. [CrossRef] [PubMed]

116. Allen, J.A.; Halverson-Tamboli, R.A.; Rasenick, M.M. Lipid raft microdomains and neurotransmitter signalling. Nat. Rev. Neurosci. 2007, 8, 128-140. [CrossRef] [PubMed]

117. Hanzal-Bayer, M.F.; Hancock, J.F. Lipid rats and membrane traffic. FEBS Lett. 2007, 581, $2098-2104$. [CrossRef] [PubMed]

118. Cordy, J.M.; Hooper, N.M.; Turner, A.J. The involvement of lipid rafts in Alzheimer's disease. Mol. Membr. Biol. 2006, 23, 111-122. [CrossRef] [PubMed]

119. Kojro, E.; Gimpl, G.; Lammich, S.; Marz, W.; Fahrenholz, F. Low cholesterol stimulates the nonamyloidogenic pathway by its effect on the $\alpha$-secretase ADAM 10. Proc. Natl. Acad. Sci. USA 2001, 98, 5815-5820. [CrossRef] [PubMed]

120. Ehehalt, R.; Keller, P.; Haass, C.; Thiele, C.; Simons, K. Amyloidogenic processing of the Alzheimer $\beta$-amyloid precursor protein depends on lipid rafts. J. Cell Biol. 2003, 160, 113-123. [CrossRef] [PubMed]

121. Hicks, D.A.; Nalivaeva, N.N.; Turner, A.J. Lipid rafts and Alzheimer's disease: Protein-lipid interactions and perturbation of signaling. Front. Physiol. 2012, 3, 189. [CrossRef] [PubMed]

122. Grimm, M.O.; Kuchenbecker, J.; Rothhaar, T.L.; Grosgen, S.; Hundsdorfer, B.; Burg, V.K.; Friess, P.; Muller, U.; Grimm, H.S.; Riemenschneider, M.; et al. Plasmalogen synthesis is regulated via alkyl-dihydorxyacetonephosphate-synthase by amyloid precursor protein processing and is affected in Alzheimer's disease. J. Neurochem. 2011, 116, 916-925. [CrossRef] [PubMed] 
123. Rothhaar, T.L.; Grosgen, S.; Haupenthal, V.J.; Burg, V.K.; Hundsdorfer, B.; Mett, J.; Riemenschneider, M.; Grimm, H.S.; Hartmann, T.; Grimm, M.O. Plasmalogens inhibit APP processing by directly affecting $\gamma$-secretase activity in Alzheimer's disease. Sci. World J. 2012, 2012. [CrossRef] [PubMed]

124. Ghosal, K.; Vogt, D.L.; Liang, M.; Shen, Y.; Lamb, B.T.; Pimplikar, S.W. Alzheimer's disease-like pathological features in transgenic mice expressing the APP intracellular domain. Proc. Natl. Acad. Sci. USA 2009, 106, 18367-18372. [PubMed]

125. Fabelo, N.; Marin, V.; Marin, R.; Moreno, D.; Ferrer, I.; Diaz, M. Altered lipid composition in cortical lipid rafts occurs at early stages of sporadic Alzheimer's disease and facilitates APP/BACE1 interactions. Neurobiol. Aging 2014, 35, 1801-1812. [CrossRef] [PubMed]

126. Geekiyanage, H.; Upadhye, A.; Chan, C. Inhibition of serine palmitoyltransferase reduces $A \beta$ and Tau hyperphosphorylation in a murine model: A safe therapeutic strategy for Alzheimer's disease. Neurobiol. Aging 2013, 34, 2037-2051. [PubMed]

127. Riemann, D.; Hansen, G.H.; Niels-Christiansen, L.L.; Thorsen, E.; Immerdal, L.; Santos, A.N.; Kehlen, A.; Langner, J.; Danielsen, E.M. Caveolae/lipid rafts in fibroblast-like synoviocytes: Ectopeptidase-rich membrane microdomains. Biochem. J. 2001, 354, 47-55. [CrossRef] [PubMed]

128. Kawarabayashi, T.; Shoji, M.; Younkin, L.H.; Wen-Lang, L.; Dickson, D.W.; Murakami, T.; Matsubara, E.; Abe, K.; Ashe, K.H.; Younkin, S.G. Dimeric amyloid $\beta$ protein rapidly accumulates in lipid rafts followed by apolipoprotein $\mathrm{E}$ and phosphorylated Tau accumulation in the Tg2576 mouse model of Alzheimer's disease. J. Neurosci. 2004, 24, 3801-3809. [CrossRef] [PubMed]

129. Bulloj, A.; Leal, M.C.; Surace, E.I.; Zhang, X.; Xu, H.; Ledesma, M.D.; Castano, E.M.; Morelli, L. Detergent resistant membrane-associated IDE in brain tissue and cultured cells: Relevance to $A \beta$ and insulin degradation. Mol. Neurodegener. 2008, 3, 22. [CrossRef] [PubMed]

130. Parkin, E.T.; Watt, N.T.; Hussain, I.; Eckman, E.A.; Eckman, C.B.; Manson, J.C.; Baybutt, H.N.; Turner, A.J.; Hooper, N.M. Cellular prion protein regulates $\beta$-secretase cleavage of the Alzheimer's amyloid precursor protein. Proc. Natl. Acad. Sci. USA 2007, 104, 11062-11067. [CrossRef] [PubMed]

131. Prybylowski, K.; Chang, K.; Sans, N.; Kan, L.; Vicini, S.; Wenthold, R.J. The synaptic localization of NR2B-containing NMDA receptors is controlled by interactions with PDZ proteins and AP-2. Neuron 2005, 47, 845-857. [CrossRef] [PubMed]

132. Um, J.W.; Strittmatter, S.M. Amyloid- $\beta$ induced signaling by cellular prion protein and Fyn kinase in Alzheimer disease. Prion 2013, 7, 37-41. [CrossRef] [PubMed]

133. De Calignon, A.; Polydoro, M.; Suarez-Calvet, M.; William, C.; Adamowicz, D.H.; Kopeikina, K.J.; Pitstick, R.; Sahara, N.; Ashe, K.H.; Carlson, G.A.; et al. Propagation of Tau pathology in a model of early Alzheimer's disease. Neuron 2012, 73, 685-697. [CrossRef] [PubMed]

134. Ronicke, R.; Mikhaylova, M.; Ronicke, S.; Meinhardt, J.; Schroder, U.H.; Fandrich, M.; Reiser, G.; Kreutz, M.R.; Reymann, K.G. Early neuronal dysfunction by amyloid $\beta$ oligomers depends on activation of NR2B-cnotaining NMDA receptors. Neurobiol. Aging 2011, 32, 2219-2228. [CrossRef] [PubMed]

135. Williamson, R.; Usardi, A.; Hanger, D.P.; Anderton, B.H. Membrane-bound $\beta$-amyloid oligomers are recruited into lipid rafts by a fyn-dependent mechanism. FASEB J. 2008, 22, 1552-1559. [CrossRef] [PubMed]

136. Gimbel, D.A.; Nygaard, H.B.; Coffey, E.E.; Gunther, E.C.; Lauren, J.; Gimbel, Z.A.; Strittmatter, S.M. Memory impairment in transgenic Alzheimer mice requires cellular prion protein. J. Neurosci. 2010, 30, 6367-6374. [CrossRef] [PubMed]

137. Balducci, C.; Beeg, M.; Stravalaci, M.; Bastone, A.; Sclip, A.; Biasini, E.; Tapella, L.; Colombo, L.; Manzoni, C.; Borsello, T.; et al. Synthetic amyloid- $\beta$ oligomers impair long-term memory independently of cellular prion protein. Proc. Natl. Acad. Sci. USA 2010, 107, 2295-2300. [CrossRef] [PubMed]

138. Calella, A.M.; Farinelli, M.; Nuvolone, M.; Mirante, O.; Moos, R.; Falsig, J.; Mansuy, I.M.; Aguzzi, A. Prion protein and A $\beta$-related synaptic toxicity impairment. EMBO Mol. Med. 2010, 2, 306-314. [CrossRef] [PubMed]

139. Kudo, W.; Lee, H.P.; Zou, W.Q.; Wang, X.; Perry, G.; Zhu, X.; Smith, M.A.; Petersen, R.B.; Lee, H.G. Cellular prion protein is essential for oligomeric amyloid- $\beta$-induced neuronal cell death. Hum. Mol. Genet. 2012, 21, 1138-1144. [CrossRef] [PubMed] 
140. Nicoll, A.J.; Panico, S.; Freir, D.B.; Wright, D.; Terry, C.; Risse, E.; Herron, C.E.; O’Malley, T.; Wadsworth, J.D.; Farrow, M.A.; et al. Amyloid- $\beta$ nanotubes are associated with prion protein-dependent synaptotoxicity. Nat. Commun. 2013, 4, 2416. [CrossRef] [PubMed]

141. Hernandez, P.; Lee, G.; Sjoberg, M.; Maccioni, R.B. Tau phosphorylation by Cdk5 and Fyn in response to amyloid peptide Abera (25-35): Involvement of lipid rafts. J. Alzheimers Dis. 2009, 16, 149-156. [PubMed]

142. Sui, Z.; Kovacs, A.D.; Maggirwar, S.B. Recruitment of active glycogen synthase kinase-3 into neuronal lipid rafts. Biochem. Biophys. Res. Commun. 2006, 345, 1643-1648. [CrossRef] [PubMed]

143. Nikolic, M.; Dudek, H.; Kwon, Y.T.; Ramos, Y.F.; Tsai, L.H. The Cdk5/p35 kinase is essential for neurite outgrowth during neuronal differentiation. Genes Dev. 1996, 10, 816-825. [CrossRef] [PubMed]

144. Kimura, T.; Ishiguro, K.; Hisanaga, S. Physiological and pathological phosphorylation of Tau by Cdk5. Front. Mol. Neurosci. 2014, 7, 65. [CrossRef] [PubMed]

145. Shukla, V.; Skuntz, S.; Pant, H.C. Deregulated Cdk5 activity is involved in inducing Alzheimer's disease. Arch. Med. Res. 2012, 43, 655-662. [CrossRef] [PubMed]

146. Mazanetz, M.P.; Fischer, P.M. Untangling Tau hyperphosphorylation in drug design for neurodegenerative diseases. Nat. Rev. Drug Discov. 2007, 6, 464-479. [CrossRef] [PubMed]

147. Lee, G.; Thangavel, R.; Sharma, V.M.; Litersky, J.M.; Bhaskar, K.; Fang, S.M.; Do, L.H.; Andreadis, A.; van Hoesen, G.; Ksiezak-Reding, H. Phosphorylation of Tau by fyn: Implications of Alzheimer's disease. J. Neurosci. 2004, 24, 2304-2312. [CrossRef] [PubMed]

148. Bhaskar, K.; Yen, S.H.; Lee, G. Disease-related modifications in Tau affect the interaction between Fyn and Tau. J. Biol. Chem. 2005, 280, 35119-35125. [CrossRef] [PubMed]

149. Ittner, L.M.; Ke, Y.D.; Delerue, F.; Bi, M.; Gladbach, A.; van Eersel, J.; Wolfing, H.; Chieng, B.C.; Christie, M.J.; Napier, I.A.; et al. Dendritic function of Tau mediates amyloid- $\beta$ toxicity in Alzheimer's disease mouse models. Cell 2010, 142, 387-397. [CrossRef] [PubMed]

150. Usardi, A.; Pooler, A.M.; Seereeram, A.M.; Reynolds, C.H.; Derkinderen, P.; Anderton, B.; Hanger, D.P.; Noble, W.; Williamson, R. Tyrosine phosphorylation of Tau regulates its interactions with Fyn SH2 domains, but not SH3 domains, altering the cellular localization of tau. FEBS J. 2011, 278, 2927-2937. [CrossRef] [PubMed]

151. Liu, F.; Shi, J.; Tranimukai, H.; Gu, J.; Gu, J.; Grundke-Iqbal, I.; Iqbal, K.; Gong, C.X. Reduced O-GlcNAcylation links lower brain glucose metabolism and Tau pathology in Alzheimer's disease. Brain 2009, 132, 1820-1832. [CrossRef] [PubMed]

152. Velliquette, R.A.; O'Connor, T.; Vassar, R. Energy inhibition elevates $\beta$-secretase levels and activity and is potentially amyloidogenic in APP transgenic mice: Possible early events in Alzheimer's disease pathogenesis. J. Neurosci. 2005, 25, 10874-10883. [CrossRef] [PubMed]

153. O'Connor, T.; Sadleir, K.R.; Maus, E.; Velliquette, R.A.; Zhao, J.; Cole, S.L.; Eimer, W.A.; Hitt, B.; Bembinster, L.A.; Lammich, S.; et al. Phosphorylation of the translation initiation factor eIF2 $\alpha$ increases BACE1 levels and promotes amyloidogenesis. Neuron 2008, 60, 988-1009. [CrossRef] [PubMed]

154. Ankarcrona, M.; Mangialasche, F.; Winblad, B. Rethinking Alzheimer's disease therapy: Are mitochondria the key? J. Alzheimers Dis. 2010, 20, S579-S590. [PubMed]

155. Jacobsen, K.T.; Iverfeldt, K. O-GlcNAcylation increases non-amyloidogenic processing of the amyloid- $\beta$ precursor protein (APP). Biochem. Biophys. Res. Commun. 2011, 404, 882-886. [CrossRef] [PubMed]

156. Liu, K.; Paterson, A.J.; Zhang, F.; McAndrew, J.; Fukuchi, K.; Wyss, J.M.; Peng, L.; Hu, Y.; Kudlow, J.E. Accumulation of protein $\mathrm{O}$-GlcNAc modification inhibits proteasomes in the brain and coincides with neuronal apoptosis in brain areas with high O-GlcNAc metabolism. J. Neurochem. 2004, 89, 1044-1055. [CrossRef] [PubMed]

157. Brister, M.A.; Pandey, A.K.; Bielska, A.A.; Zondlo, N.J. OGlcNAcylation and phosphorylation have opposing structural effects in Tau: Phosphothreonine induces particular conformational order. J. Am. Chem. Soc. 2014, 136, 3803-3816. [CrossRef] [PubMed]

158. Iqbal, K.; Alonso Adel, C.; Chen, S.; Chohan, M.O.; El-Akkad, E.; Gong, C.X.; Khatoon, S.; Li, B.; Liu, F.; Rahman, A.; et al. Tau pathology in Alzheimer disease and other tauopathies. Biochim. Biophys. Acta 2005, 1739, 198-210. [CrossRef] [PubMed]

159. Liu, F.; Iqbal, K.; Grundke-Igbal, I.; Hart, G.W.; Gong, C.X. O-GlcNAcylation regulates phosphorylation of Tau: A mechanism involved in Alzheimer's disease. Proc. Natl. Acad. Sci. USA 2004, 101, 10804-10809. [CrossRef] [PubMed] 
160. Tallent, M.K.; Varghis, N.; Skorobogatko, Y.; Hernandez-Cuebas, L.; Whelan, K.; Vocadlo, D.J.; Vosseller, K. In vivo modulation of $O$-GlcNAc levels regulates hippocampal synaptic plasticity through interplay with phosphorylation. J. Biol. Chem. 2009, 284, 174-181. [CrossRef] [PubMed]

161. Gella, A.; Durany, N. Oxidative stress in Alzheimer disease. Cell Adh. Migr. 2009, 3, 88-93. [CrossRef] [PubMed]

162. Pocernich, C.B.; Butterfield, D.A. Elevation of glutathione as a therapeutic strategy in Alzheimer disease. Biochim. Biophys. Acta 2012, 1822, 625-630. [PubMed]

163. Liu, R.; Choi, J. Age-associated decline in $\gamma$-glutamylcysteine synthetase gene expression in rats. Free Radic. Biol. Med. 2000, 28, 566-574. [CrossRef]

164. Saharan, S.; Mandal, P.K. The emerging role of glutathione in Alzheimer's disease. J. Alzheimers Dis. 2014, 40, 519-529. [PubMed]

165. Lee, M.; Cho, T.; Jantaratnotai, N.; Wang, Y.T.; McGeer, E.; McGeer, P.L. Depletion of GSH in glial cells induces neurotoxicity: Relevance to aging and degenerative neurological diseases. FASEB J. 2010, 24, 2533-2545. [CrossRef] [PubMed]

166. Shen, C.; Chen, Y.; Liu, H.; Zhang, K.; Zhang, T.; Lin, A.; Jing, N. Hydrogen peroxide promotes A $\beta$ production through JNK-dependent activation of $\gamma$-secretase. J. Biol. Chem. 2008, 283, 17721-17730. [CrossRef] [PubMed]

167. Anantharaman, M.; Tangpong, J.; Keller, J.N.; Murphy, M.P.; Markesbery, W.R.; Kiningham, K.K., St.; Clair, D.K. $\beta$-amyloid mediated nitration of manganese superoxide dismutase: Implication for oxidative stress in a APPNLH/NLH X PS-1P264L/P264L double knock-in mouse model of Alzheimer's disease. Am. J. Pathol. 2006, 168, 1608-1617. [CrossRef] [PubMed]

168. Lovell, M.A.; Robertson, J.D.; Teesdale, W.J.; Campbell, J.L.; Markesbery, W.R. Copper, iron and zinc in Alzheimer's disease senile plaques. J. Neurol. Sci. 1998, 158, 47-52. [CrossRef]

169. Atwood, C.S.; Scarpa, R.C.; Huang, X.; Moir, R.D.; Jones, W.D.; Fairlie, D.P.; Tanzi, R.E.; Bush, A.I. Characterization of copper interactions with Alzheimer amyloid $\beta$ peptides: Identification of an attomolar-affinity copper binding site on amyloid $\beta 1-42$. J. Neurochem. 2000, 75, 1219-1233. [CrossRef] [PubMed]

170. Huang, X.; Cuajungco, M.P.; Atwood, C.S.; Hartshorn, M.A.; Tyndall, J.D.; Hanson, G.R.; Stokes, K.C.; Leopold, M.; Multhaup, G.; Goldstein, L.E.; et al. $\mathrm{Cu}(\mathrm{II})$ potentiation of Alzheimer A $\beta$ neurotoxicity. Correlation with cell-free hydrogen peroxide production and metal reduction. J. Biol. Chem. 1999, 274, 37111-37116. [CrossRef] [PubMed]

171. Al-Hilaly, Y.K.; Williams, T.L.; Stewart-Parker, M.; Ford, L.; Skaria, E.; Cole, M.; Bucher, W.G.; Morris, K.L.; Sada, A.A.; Thorpe, J.R.; et al. A central role for dityrosine crosslinking of amyloid- $\beta$ in Alzheimer's disease. Acta Neuropathol. Commun. 2013, 1, 83. [CrossRef] [PubMed]

172. Hensley, K.; Maidt, M.L.; Yu, Z.; Sang, H.; Markesbery, W.R.; Floyd, R.A. Electrochemical analysis of protein nitrotyrosine and dityrosine in the Alzheimer brain indicates region-specific accumulation. J. Neurosci. 1998, 18, 8126-8132. [PubMed]

173. Cuajungco, M.P.; Goldstein, L.E.; Nunomura, A.; Smith, M.A.; Lim, J.T.; Atwood, C.S.; Huang, X.; Farrag, Y.W.; Perry, G.; Bush, A.I. Evidence that the $\beta$-amyloid plaques of Alzheimer's disease represent the redox-silencing and entombment of $\mathrm{A} \beta$ by zinc. J. Biol. Chem. 2000, 275, 19439-19442. [CrossRef] [PubMed]

174. Craddock, T.J.; Tuszynski, J.A.; Chopra, D.; Casey, N.; Goldstein, L.E.; Hameroff, S.R.; Tanzi, R.E. The zinc dyshoemostasis hypothesis of Alzheimer's disease. PLoS ONE 2012, 7, e33552. [CrossRef] [PubMed]

175. Yan, S.D.; Chen, X.; Fu, J.; Chen, M.; Zhu, H.; Roher, A.; Slattery, T.; Zhao, L.; Nagashima, M.; Morser, J.; et al . RAGE and amyloid- $\beta$ peptide neurotoxicity in Alzheimer's disease. Nature 1996, 382, 685-691. [CrossRef] [PubMed]

176. Bierhaus, A.; Humpert, P.M.; Morcos, M.; Wendt, T.; Chavakis, T.; Arnold, B.; Stern, D.M.; Nawroth, P.P. Understanding RAGE, the receptor for advanced glycation end products. J. Mol. Med. 2005, 83, 876-886. [CrossRef] [PubMed]

177. Srikanth, V.; Maczurek, A.; Phan, T.; Steele, M.; Westcott, B.; Juskiw, D.; Munch, G. Advanced glycation endproducts and their receptor RAGE in Alzheimer's disease. Neurobiol. Aging 2011, 32, 763-777. [CrossRef] [PubMed] 
178. Valente, T.; Gella, A.; Fernandez-Busquets, X.; Unzeta, M.; Durany, N. Immunohistochemical analysis of human brain suggests pathological synergism of Alzheimer's disease and diabetes mellitus. Neurobiol. Dis. 2010, 37, 67-76. [CrossRef] [PubMed]

179. Cho, H.J.; Son, S.M.; Jin, S.M.; Hong, H.S.; Shin, D.H.; Kim, S.J.; Huh, K.; Mook-Jung, I. RAGE regulates BACE1 and A $\beta$ generation via NFAT1 activation in Alzheimer's disease animal model. FASEB J. 2009, 23, 2639-2649. [CrossRef] [PubMed]

180. Yan, S.D.; Bierhaus, A.; Nawroth, P.P.; Stern, D.M. RAGE and Alzheimer's disease: A progression factor for amyloid- $\beta$-induced cellular perturbation? J. Alzheimers Dis. 2009, 16, 833-843. [PubMed]

181. Martel, C.L.; Mackic, J.B.; McComb, J.G.; Ghiso, J.; Zlokovic, B.V. Blood-brain barrier uptake of the 40 and 42 amino acid sequences of circulating Alzheimer's amyloid $\beta$ in guinea pigs. Neurosci. Lett. 1996, 206, 157-160. [CrossRef]

182. Deane, R.; du Yan, S.; Submamaryan, R.K.; LaRue, B.; Jovanovic, S.; Hogg, E.; Welch, D.; Manness, L.; Lin, C.; Yu, J.; et al. RAGE mediates amyloid- $\beta$ peptide transport across the blood-brain barrier and accumlation in brain. Nat. Med. 2003, 9, 907-913. [CrossRef] [PubMed]

183. Manolopoulos, K.N.; Klotz, L.O.; Korsten, P.; Bornstein, S.R.; Barthel, A. Linking Alzheimer's disease to insulin resistance: The FoxO response to oxidative stress. Mol. Psychiatry 2010, 15, 1046-1052. [CrossRef] [PubMed]

184. Hardas, S.S.; Sultana, R.; Clark, A.M.; Beckett, T.L.; Szweda, L.I.; Murphy, M.P.; Butterfield, D.A. Oxidative modification of lipoic acid by HNE in Alzheimer disease brain. Redox Biol. 2013, 1, 80-85. [CrossRef] [PubMed]

185. Siegel, S.J.; Bieschke, J.; Powers, E.T.; Kelly, J.W. The oxidative stress metabolite 4-hydroxynonenal promotes Alzheimer protofibril formation. Biochemistry 2007, 46, 1503-1510. [CrossRef] [PubMed]

186. Markesbery, W.R.; Lovell, M.A. Four-hydroxynonenal, a product of lipid peroxidation, is increased in the brain in Alzheimer's disease. Neurobiol. Aging 1998, 19, 33-36. [CrossRef]

187. Schulingkamp, R.J.; Pagano, T.C.; Hung, D.; Raffa, R.B. Insulin receptors and insulin action in the brain: Review and clinical implications. Neurosci. Biobehav. Rev. 2000, 24, 855-872. [CrossRef]

188. Dore, S.; Kar, S.; Quirion, R. Insulin-like growth factor I protects and rescues hippocampal neurons against $\beta$-amyloid- and human amylin-induced toxicity. Proc. Natl. Acad. Sci. USA 1997, 94, 4772-4777. [CrossRef] [PubMed]

189. Fernandez, A.M.; Torres-Aleman, I. The many faces of insulin-like peptide signalling in the brain. Nat. Rev. Neurosci. 2012, 13, 225-239. [CrossRef] [PubMed]

190. Wozniak, M.; Rydzewski, B.; Baker, S.P.; Raizada, M.K. The cellular and physiological actions of insulin in the central nervous system. Neurochem. Int. 1993, 22, 1-10. [CrossRef]

191. Sesti, G.; Federici, M.; Hribal, M.L.; Lauro, D.; Sbraccia, P.; Lauro, R. Defects of the isnulin receptor substrate (IRS) system in human metabolic disorders. FASEB J. 2001, 15, 2099-2111. [CrossRef] [PubMed]

192. White, M.F. Insulin signaling in health and disease. Science 2003, 302, 1710-1711. [CrossRef] [PubMed]

193. Schubert, M.; Brazil, D.P.; Burks, D.J.; Kushner, J.A.; Ye, J.; Flint, C.L.; Farhang-Fallah, J.; Dikkes, P.; Warot, X.M.; Rio, C.; et al. Insulin receptor substrate-2 deficiency impairs brain growth and promotes Tau phosphorylation. J. Neurosci. 2003, 23, 7084-7092. [PubMed]

194. Schubert, M.; Gautam, D.; Surjo, D.; Ueki, K.; Baudler, S.; Schubert, D.; Kondo, T.; Alber, J.; Galldiks, N.; Kustermann, E.; et al. Role for neuronal insulin resistance in neurodegenerative diseases. Proc. Natl. Acad. Sci. USA 2004, 101, 3100-3105. [CrossRef] [PubMed]

195. Cheng, C.M.; Tseng, V.; Wang, J.; Wang, D.; Matyakhina, L.; Bondy, C.A. Tau is hyperphosphorylated in the insulin-like growth factor-I null brain. Endocrinology 2005, 146, 5086-5091. [CrossRef] [PubMed]

196. Killick, R.; Scales, G.; Leroy, K.; Causevic, M.; Hooper, C.; Irvine, E.E.; Choudhury, A.I.; Drinkwater, L.; Kerr, F.; Al-Qassab, H.; et al. Deletion of Irs2 reduces amyloid deposition and rescues behavioural deficits in APP transgenic mice. Biochem. Biophys. Res. Commun. 2009, 386, 257-262. [CrossRef] [PubMed]

197. Moloney, A.M.; Griffin, R.J.; Timmons, S.; O'Connor, R.; Ravid, R.; O’Neil, C. Defects in IGF-1 receptor, insulin receptor and IRS-1/2 in Alzheimer's disease indicate possible resistance to IGF-1 and insulin signalling. Neurobiol. Aging 2010, 31, 224-243. [CrossRef] [PubMed]

198. Cross, D.A.; Alessi, D.R.; Cohen, P.; Andjelkovich, M.; Hemmings, B.A. Inhibition of glycogen synthase kinase-3 by insulin mediated by protein kinase B. Nature 1995, 378, 785-789. [CrossRef] [PubMed] 
199. Alessi, D.R.; Cohen, P. Mechanism of activation and function of protein kinase B. Curr. Opin. Genet. Dev. 1998, 8, 55-62. [CrossRef]

200. Frolich, L.; Blum-Degen, D.; Bernstein, H.G.; Engelsberger, B.S.; Humrich, J.; Laufer, S.; Muschner, D.; Thalheimer, A.; Turk, A.; Hoyer, S.; et al. Brain insulin and insulin receptors in aging and sporadic Alzheimer's disease. J. Neural Transm. 1998, 105, 423-438. [CrossRef] [PubMed]

201. Hotamisligil, G.S.; Peraldi, P.; Budavari, A.; Ellis, R.; White, M.F.; Spiegelman, B.M. IRS-1-mediated inhibition of insulin receptor tyrosine kinase activity in TNF- $\alpha$ - and obesity-induced insulin resistance. Science 1996, 271, 665-668. [CrossRef] [PubMed]

202. Aguirre, V.; Werner, E.D.; Giraud, J.; Lee, Y.H.; Shoelson, S.E.; White, M.F. Phosphorylation of Ser307 in insulin receptor substrate- 1 blocks interactions with the insulin receptor and inhibits insulin action. J. Biol. Chem. 2002, 277, 1531-1537. [CrossRef] [PubMed]

203. Paz, K.; Hemi, R.; LeRoith, D.; Karasik, A.; Elhanany, E.; Kanety, H.; Zick, Y. A molecular basis for insulin resistance. Elevated serine/threonine phosphorylation of IRS-1 and IRS-2 inhibits their binding to the juxtamembrane region of the insulin and impairs their ability to undergo insulin-induced tyrosine phosphorylation. J. Biol. Chem. 1997, 272, 29911-29918. [CrossRef] [PubMed]

204. De Felice, F.G.; Lourenco, M.V.; Ferreira, S.T. How does brain insulin resistance develop in Alzheimer's disease? Alzheimers Dement. 2014, 10, S26-S32. [CrossRef] [PubMed]

205. Butterfield, D.A.; di Domenico, F.; Barone, E. Elevated risk of type 2 diabetes for development of Alzheimer disease: A key role for oxidative stress in brain. Biochim. Biophys. Acta 2014, 1842, 1693-1706. [CrossRef] [PubMed]

206. Dou, J.T.; Chen, M.; Dufour, F.; Alkon, D.L.; Zhao, W.Q. Insulin receptor signaling in long-term memory consolidation following spatial learning. Learn. Mem. 2005, 12, 646-655. [CrossRef] [PubMed]

207. Cole, G.M.; Frautschy, S.A. The role of insulin and neurotrophic factor signaling in brain aging and Alzheimer's disease. Exp. Gerontol. 2007, 42, 10-21. [CrossRef] [PubMed]

208. Zhao, W.Q.; Lacor, P.N.; Chen, H.; Lambert, M.P.; Quon, M.J.; Krafft, G.A.; Klein, W.L. Insulin receptor dysfunction impairs cellular clearance of neurotoxic oligomeric A $\beta$. J. Biol. Chem. 2009, 284, 18742-18753. [CrossRef] [PubMed]

209. Vekrellis, K.; Ye, Z.; Qiu, W.Q.; Walsh, D.; Hartley, D.; Chesneau, V.; Rosner, M.R.; Selkoe, D.J. Neurons regulate extracellular levels of amyloid $\beta$-protein via proteolysis by insulin-degrading enzyme. J. Neurosci. 2000, 20, 1657-1665. [PubMed]

210. Zhao, L.; Teter, B.; Morihara, T.; Lim, G.P.; Ambegaokar, S.S.; Ubeda, O.J.; Frautschy, S.A.; Cole, G.M. Insulin-degrading enzyme as a downstream target of insulin receptor signaling cascade: Implications for Alzheimer's disease intervention. J. Neurosci. 2004, 24, 11120-11126. [CrossRef] [PubMed]

211. Reger, M.A.; Watson, G.S.; Green, P.S.; Baker, L.D.; Cholerton, B.; Fishel, M.A.; Plymate, S.R.; Cherrier, M.M.; Schellenberg, G.D.; Frey, W.H., II; et al. Intranasal insulin administration dose-dependently modulates verbal memory and plasma amyloid- $\beta$ in memory-impaired older adults. J. Alzheimers Dis. 2008, 13, 323-331. [PubMed]

212. Cook, D.G.; Leverenz, J.B.; McMillan, P.J.; Kulstad, J.J.; Ericksen, S.; Roth, R.A.; Schellenberg, G.D.; Jin, L.W.; Kovacina, K.S.; Craft, S. Reduced hippocampal insulin-degrading enzyme in late-onset Alzheimer's disease is associated with the apolipoprotein E-epsiron4 allele. Am. J. Pathol. 2003, 162, 313-319. [CrossRef]

213. Pelvig, D.P.; Pakkenberg, H.; Stark, A.K.; Pakkenberg, B. Neocortical glial cell numbers in human brains. Neurobiol. Aging 2008, 29, 1754-1762. [CrossRef] [PubMed]

214. Derecki, N.C.; Katzmarski, N.; Kipnis, J.; Meyer-Luehmann, M. Microglia as a critical player in both developmental and late-life CNS pathogenesis. Acta Neuropathol. 2014, 128, 333-345. [CrossRef] [PubMed]

215. Ekdahl, C.T.; Claasen, J.H.; Bonde, S.; Kokaia, Z.; Lindvall, O. Inflammation is detrimental for neurogenesis in adult brain. Proc. Natl. Acad. Sci. USA 2003, 100, 13632-13637. [CrossRef] [PubMed]

216. Monje, M.L.; Toda, H.; Palmer, T.D. Inflammatory blockade restores adult hippocampal neurogenesis. Science 2003, 302, 1760-1765. [CrossRef] [PubMed]

217. Ziv, Y.; Ron, N.; Butovsky, O.; Landa, G.; Greenberg, N.; Cohen, H.; Kipnis, J.; Schwartz, M. Immune cells contribute to the maintenance of neurogenesis and spatial learning abilities in adulthood. Nat. Neurosci. 2006, 9, 268-275. [CrossRef] [PubMed] 
218. Li, Y.; Liu, L.; Barger, S.W.; Griffin, W.S. Interleukin-1 mediates pathological effects of microglia on Tau phosphorylation and on synaptophysin synthesis in cortical neurons through a p38-MAPK pathway. J. Neurosci. 2003, 23, 1605-1611. [PubMed]

219. Harrison, J.K.; Jiang, Y.; Chen, S.; Xia, Y.; Maciejewski, D.; McNamara, R.K.; Streit, W.J.; Salafranca, M.N.; Adhikari, S.; Thompson, D.A.; et al. Role for neuronally derived fractalkine in mediating interactions between neurons and CX3CR1-expressing microglia. Proc. Natl. Acad. Sci. USA 1998, 95, 10896-10901. [CrossRef] [PubMed]

220. Hatori, H.; Nagai, A.; Heisel, R.; Ryu, J.K.; Kim, S.U. Fractalkine and fractalkine receptors in human neurons and glial cells. J. Neurosci. Res. 2002, 69, 418-426. [CrossRef] [PubMed]

221. Re, D.B.; Przedborski, S. Fractalkine: Moving from chemotaxis to neuroprotection. Nat. Neurosci. 2006, 9, 859-861. [PubMed]

222. Lyons, A.; Lynch, A.M.; Downer, E.J.; Hanley, R.; O'Sullivan, J.B.; Smith, A.; Lynch, M.A. Fractalkine-induced activation of the phosphatidylinositol-3 kinase pathway attenuates microglial activation in vivo and in vitro. J. Neurochem. 2009, 110, 1547-1556. [CrossRef] [PubMed]

223. Deiva, K.; Geeraerts, T.; Salim, H.; Leclerc, P.; Hery, C.; Hugel, B.; Freyssinet, J.M.; Tardieu, M. Fractalkine reduces $N$-methyl-D-aspartate-induced calcium flux and apoptosis in human neurons through extracellular signal-regulated kinase activation. Eur. J. Neurosci. 2004, 20, 3222-3232. [CrossRef] [PubMed]

224. Limatola, C.; Lauro, C.; Catalano, M.; Ciotti, M.T.; Bertollini, C.; di Angelantonio, S.; Ragozzino, D.; Eusebi, F. Chemokine CX3CL1 protects rat hippocampal neurons against glutamate-mediated excitotoxicity. J. Neuroimmunol. 2005, 166, 19-28. [CrossRef] [PubMed]

225. Kim, T.S.; Lim, H.K.; Lee, J.Y.; Kim, D.J.; Park, S.; Lee, C.; Lee, C.U. Changes in the levels of plasma soluble fractalkine in patients with mild cognitive impairment and Alzheimer's disease. Neurosci. Lett. 2008, 436, 196-200. [CrossRef] [PubMed]

226. Cho, S.H.; Sun, B.; Zhou, Y.; Kauppinen, T.M.; Halabisky, B.; Wes, P.; Ransohoff, R.M.; Gan, L. CX3CR1 protein signaling modulates microglial activation and protects against plaque-independent cognitive deficits in a mouse model of Alzheimer disease. J. Biol. Chem. 2011, 286, 32713-32722. [CrossRef] [PubMed]

227. Lyons, A.; Downer, E.J.; Crotty, S.; Nolan, Y.M.; Mills, K.H.; Lynch, M.A. CD200 ligand receptor interaction modulates microglial activation in vivo and in vitro: A role for IL-4. J. Neurosci. 2007, 27, 8309-8313. [CrossRef] [PubMed]

228. Hernangomez, M.; Carrillo-Salinas, F.J.; Mecha, M.; Correa, F.; Mestre, L.; Loria, F.; Feliu, A.; Docagne, F.; Guaza, C. Brain innate immunity in the regulation of neuroinflammation: Therapeutic strategies by modulating CD200-CD200R interaction involve the cannabinoid system. Curr. Pharm. Des. 2014, 20, 4707-4722. [CrossRef] [PubMed]

229. Cox, F.F.; Carney, D.; Miller, A.M.; Lynch, M.A. CD200 fusion protein decreases microglial activation in the hippocampus of aged rats. Brain Behav. Immun. 2012, 26, 789-796. [CrossRef] [PubMed]

230. Frank, M.G.; Barrientos, R.M.; Biedenkapp, J.C.; Rudy, J.W.; Watkins, L.R.; Maier, S.F. mRNA up-regulation of MHC II and pivotal pro-inflammatory genes in normal brain aging. Neurobiol. Aging 2006, 27, 717-722. [CrossRef] [PubMed]

231. Walker, D.G.; Dalsing-Hernandez, J.E.; Campbell, N.A.; Lue, L.F. Decreased expression of CD200 and CD200 receptor in Alzheimer's disease: A potential mechanism leading to chronic inflammation. Exp. Neurol. 2009, 215, 5-19. [CrossRef] [PubMed]

232. Costello, D.A.; Lyons, A.; Denieffe, S.; Browne, T.C.; Cox, F.F.; Lynch, M.A. Long term potentiation is impaired in membrane glycoprotein CD200-deficient mice: A role for Toll-like receptor activation. J. Biol. Chem. 2011, 286, 34722-34732. [CrossRef] [PubMed]

233. Okun, E.; Mattson, M.P.; Arumugam, T.V. Involvement of FC receptors in disorders of the central nervous system. Neuromol. Med. 2010, 12, 164-178. [CrossRef] [PubMed]

234. Guilliams, M.; Bruhns, P.; Saeys, Y.; Hammad, H.; Lambrecht, B.N. The function of Fc $\gamma$ receptors in dendritic cells and macrophages. Nat. Rev. Immunol. 2014, 14, 94-108. [CrossRef] [PubMed]

235. Gaikwad, S.; Larionov, S.; Wang, Y.; Dannenberg, H.; Matozaki, T.; Monsonego, A.; Thal, D.R.; Neumann, H. Signal regulatory protein- $\beta 1$ : A microglial modulator of phagocytosis in Alzheimer's disease. Am. J. Pathol. 2009, 175, 2528-2539. [CrossRef] [PubMed]

236. Doens, D.; Fernandez, P.L. Microglia receptors and their implications in the response to amyloid $\beta$ for Alzheimer's disease pathogenesis. J. Neuroinflamm. 2014, 11, 48. [CrossRef] [PubMed] 
237. Qiu, W.Q.; Ye, Z.; Kholodenko, D.; Seubert, P.; Selkoe, D.J. Degradation of amyloid $\beta$-protein by a metalloprotease secreted by microglia and other neural and non-neural cells. J. Biol. Chem. 1997, 272, 6641-6646. [CrossRef] [PubMed]

238. Qiu, W.Q.; Walsh, D.M.; Ye, Z.; Vekrellis, K.; Zhang, J.; Podlisny, M.B.; Rosner, M.R.; Safavi, A.; Hersh, L.B.; Selkoe, D.J. Insulin-degrading enzyme regulates extracellular levels of amyloid $\beta$-protein by degradation. J. Biol. Chem. 1998, 273, 32730-32738. [CrossRef] [PubMed]

239. Carson, J.A.; Turner, A.J. $\beta$-amyloid catabolism: Roles for neprilysin (NEP) and other metallopeptidases? J. Neurochem. 2002, 81, 1-8. [CrossRef] [PubMed]

240. Sakamoto, M.; Miyamoto, K.; Wu, Z.; Nakanishi, H. Possible involvement of cathepsin B released by microglia in methylmercury-induced cerebellar pathological changes in the adult rat. Neurosci. Lett. 2008, 442, 292-296. [CrossRef] [PubMed]

241. Mosher, K.I.; Wyss-Coray, T. Microglial dysfunction in brain aging and Alzheimer's disease. Biochem. Pharmacol. 2014, 88, 594-604. [CrossRef] [PubMed]

242. Lucin, K.M.; O’Brien, C.E.; Bieri, G.; Czirr, E.; Mosher, K.I.; Abbey, R.J.; Mastroeni, D.F.; Rogers, J.; Spencer, B.; Masliah, E.; et al. Microglial beclin 1 regulates retromer trafficking and phagocytosis and is impaired in Alzheimer's disease. Neuron 2013, 79, 873-886. [CrossRef] [PubMed]

243. Lamkanfi, M.; Vande Walle, L.; Kanneganti, T.D. Deregulated inflammasome signaling in disease. Immunol. Rev. 2011, 243, 163-173. [CrossRef] [PubMed]

244. Koenigsknecht-Talboo, J.; Landreth, G.E. Microglial phagocytosis induced by fibrillar $\beta$-amyloid and IgGs are differentially regulated by proinflammatory cytokines. J. Neurosci. 2005, 25, 8240-8249. [CrossRef] [PubMed]

245. Heneka, M.T.; Kummer, M.P.; Stutz, A.; Delekate, A.; Schwartz, S.; Vieira-Saecker, A.; Griep, A.; Axt, D.; Remus, A.; Tzeng, T.; et al. NLRP3 is activated in Alzheimer's disease and contributes to pathology in APP/PS1 mice. Nature 2013, 493, 674-678. [CrossRef] [PubMed]

246. Nagelhus, E.A.; Amiry-Moghaddam, M.; Bergersen, L.H.; Bjaalie, J.G.; Eriksson, J.; Gundersen, V.; Leergaard, T.B.; Morth, J.P.; Storm-Mathisen, J.; Trop, R.; et al. The glia doctorine: Addressing the role of glial cells in healthy brain ageing. Mech. Ageing Dev. 2013, 134, 449-459. [CrossRef] [PubMed]

247. Choi, S.S.; Lee, H.J.; Lim, I.; Satoh, J.; Kim, S.U. Human astrocytes: Secretome profiles of cytokines and chemokines. PLoS ONE 2014, 9, e92325. [CrossRef] [PubMed]

248. Sykova, E. Glial diffusion barriers during aging and pathological states. Prog. Brain Res. 2001, 132, $339-363$. [PubMed]

249. Vargova, L.; Sykova, E. Astrocytes and extracellular matrix in extrasynaptic volume transmission. Philos. Trans. R. Soc. Lond. B 2014, 369. [CrossRef] [PubMed]

250. Swanson, R.A.; Ying, W.; Kauppinen, T.M. Astrocyte influences on ischemic neuronal death. Curr. Mol. Med. 2004, 4, 193-205. [CrossRef] [PubMed]

251. Pekny, M.; Wilhelmsson, U.; Bogestal, Y.R.; Pekna, M. The role of astrocytes and complement system in neural plasticity. Int. Rev. Neurobiol. 2007, 82, 95-111. [PubMed]

252. Apelt, J.; Schliebs, R. $\beta$-amyloid-induced glial expression of both pro- and anti-inflammatory cytokines in cerebral cortex of aged transgenic Tg2576 mice with Alzheimer plaque pathology. Brain Res. 2001, 894, 21-30. [CrossRef]

253. Papadopoulos, M.C.; Verkman, A.S. Aquaporin water channels in the nervous system. Nat. Rev. Neurosci. 2013, 14, 265-277. [CrossRef] [PubMed]

254. Butterfield, D.A.; Pocernich, C.B. The glutamatergic system and Alzheimer's disease: Therapeutic implications. CNS Drugs 2003, 17, 641-652. [CrossRef] [PubMed]

255. Lauderback, C.M.; Hackett, J.M.; Huang, F.F.; Keller, J.N.; Szweda, L.I.; Markesbery, W.R.; Butterfield, D.A. The glial glutamate transporter, GLT-1, is oxidatively modified by 4-hydroxy-2-nonenal in the Alzheimer's disease brain: The role of A $\beta 1-42$. J. Neurochem. 2001, 78, 413-416. [CrossRef] [PubMed]

256. Masliah, E.; Alford, M.; de Teresa, R.; Mallory, M.; Hansen, L. Deficient glutamate transport is associated with neurodegeneration in Alzheimer's disease. Ann. Neurol. 1996, 40, 759-766. [CrossRef] [PubMed]

257. Korn, T.; Magnus, T.; Jung, S. Autoantigen specific T cells inhibit glutamate uptake in astrocytes by decreasing expression of astrocytic glutamate transporter GLAST: A mechanism mediated by tumor necrosis factor- $\alpha$. FASEB J. 2005, 19, 1878-1880. [CrossRef] [PubMed] 
258. Zou, J.; Wang, Y.X.; Dou, F.F.; Lu, H.Z.; Ma, Z.W.; Lu, P.H.; Xu, X.M. Glutamine synthetase down-regulation reduces astrocyte protection against glutamate excitotoxicity to neurons. Neurochem. Int. 2010, 56, 577-584. [CrossRef] [PubMed]

259. Olabarria, M.; Noristani, H.N.; Verkhratsky, A.; Rodriguez, J.J. Age-dependent decrease in glutamine synthetase expression in the hippocampal astroglia of the triple transgenic Alzheimer's disease mouse model: Mechanism of deficient glutamategic transmission? Mol. Neurodegener. 2011, 6, 55. [CrossRef] [PubMed]

260. Kulijewicz-Nawrot, M.; Verkhratsky, A.; Chvatal, A.; Sykova, E.; Rodriguez, J.J. Astrocytic cytoskeletal atrophy in the medial prefrontal cortex of a triple transgenic mouse model of Alzheimer's disease. J. Anat. 2012, 221, 252-262. [CrossRef] [PubMed]

261. Oberstein, T.J.; Spitzer, P.; Klafki, H.W.; Linning, P.; Neff, F.; Knolker, H.J.; Lewczuk, P.; Wiltfang, J.; Kornhuber, J.; Maler, J.M. Astrocytes and microglia but not neurons preferentially generate $N$-terminally truncated A $\beta$ peptides. Neurobiol. Dis. 2015, 73, 24-35. [CrossRef] [PubMed]

262. Yin, K.J.; Cirrito, J.R.; Yan, P.; Hu, X.; Xiao, Q.; Pan, X.; Bateman, R.; Song, H.; Hsu, F.F.; Turk, J.; et al. Matrix metalloproteinases expressed by astrocytes mediate extracellular amyloid- $\beta$ peptide catabolism. J. Neurosci. 2006, 26, 10939-10948. [CrossRef] [PubMed]

263. Kanemitsu, H.; Tomiyama, T.; Mori, H. Human neprilysin is capable of degrading amyloid $\beta$ peptide not only in the monomeric form but also the pathological oligomeric form. Neurosci. Lett. 2003, 350, 113-116. [CrossRef]

264. Eckman, E.A.; Eckman, C.B. A $\beta$-degrading enzymes: Modulators of Alzheimer's disease pathogenesis and targets for therapeutic intervention. Biochem. Soc. Trans. 2005, 33, 1101-1105. [CrossRef] [PubMed]

265. Elshourbagy, N.A.; Liao, W.S.; Mahley, R.W.; Taylor, J.M. Apolipoprotein E mRNA is abundant in the brain and adrenals, as well as in the liver, and is present in other peripheral tissues of rats and marmosets. Proc. Natl. Acad. Sci. USA 1985, 82, 203-207. [CrossRef] [PubMed]

266. Pitas, R.E.; Boyles, J.K.; Lee, S.H.; Foss, D.; Mahley, R.W. Astrocytes synthesize apolipoprotein E and metabolize apolipoprotein E-containing lipoproteins. Biochim. Biophys. Acta 1987, 917, 148-161. [CrossRef]

267. Nakai, M.; Kawamata, T.; Taniguchi, T.; Maeda, K.; Tanaka, C. Expression of apolipoprotein E mRNA in rat microglia. Neurosci. Lett. 1996, 211, 41-44. [CrossRef]

268. Hatters, D.M.; Peters-Libeu, C.A.; Weisgraber, K.H. Apolipoprotein E structure: Insights into function. Trends Biochem. Sci. 2006, 31, 445-454. [CrossRef] [PubMed]

269. Kanekiyo, T.; Xu, H.; Bu, G. ApoE and A $\beta$ in Alzheimer's disease: Accidental encounters or partners? Neuron 2014, 81, 740-754. [CrossRef] [PubMed]

270. Holtzman, D.M.; Herz, J.; Bu, G. Apolipoprotein E and apolipoprotein E receptors: Normal biology and role in Alzheimer disease. Cold Spring Harb. Perspect. Med. 2012, 2. [CrossRef] [PubMed]

271. Basak, J.M.; Verghese, P.B.; Yoon, H.; Kim, J.; Hotzman, D.M. Low-density lipoprotein receptor represent an apolipoprotein E-independent pathway of $\mathrm{A} \beta$ uptake and degradation by astrocytes. J. Biol. Chem. 2012, 287, 13959-13971. [CrossRef] [PubMed]

272. Myung, N.H.; Zhu, X.; Kruman, I.I.; Castellani, R.J.; Petersen, R.B.; Siedlak, S.L.; Perry, G.; Smith, M.A.; Lee, H.G. Evidence of DNA damage in Alzheimer disease: Phosphorylation of histone H2AX in astrocytes. Age 2008, 30, 209-215. [CrossRef] [PubMed]

273. Bhat, R.; Crowe, E.P.; Bitto, A.; Moh, M.; Katsetos, C.D.; Garcia, F.U.; Johnson, F.B.; Trojanowski, J.Q.; Sell, C.; Torres, C. Astrocyte senescence as a component of Alzheimer's disease. PLoS ONE 2012, 7, e45069. [CrossRef] [PubMed]

274. Oakley, H.; Cole, S.L.; Logan, S.; Maus, E.; Shao, P.; Craft, J.; Guillozet-Bongaarts, A.; Ohno, M.; Disterhoft, J.; van Eldik, L.; et al. Intraneuronal $\beta$-amyloid aggregates, neurodegeneration, and neuron loss in transgenic mice with five familial Alzheimer's disease mutations: Potential factors in amyloid plaque formation. J. Neurosci. 2006, 26, 10129-10140. [CrossRef] [PubMed]

275. Oddo, S.; Caccamo, A.; Kitazawa, M.; Tseng, B.P.; LaFerla, F.M. Amyloid deposition precedes tangle formation in a triple transgenic model of Alzheimer's disease. Neurobiol. Aging 2003, 24, 1063-1070. [CrossRef] [PubMed]

276. Rohn, T.T.; Vyas, V.; Hernandez-Estrada, T.; Nichol, K.E.; Christie, L.A.; Head, E. Lack of pathology in a triple transgenic mouse model of Alzheimer's disease after overexpression of the anti-apoptotic protein Bcl-2. J. Neurosci. 2008, 28, 3051-3059. [CrossRef] [PubMed] 
277. Akiyama, H.; Barger, S.; Barnum, S.; Bradt, B.; Bauer, J.; Cole, G.M.; Cooper, N.R.; Eikelenboom, P.; Emmerling, M.; Fiebich, B.L.; et al. Inflammation and Alzheimer's disease. Neurobiol. Aging 2000, 21, 383-421. [CrossRef]

278. Montkowski, A.; Poetting, M.; Mederer, A.; Holsboer, F. Behavioural performance in three substrains of mouse strain 129. Brain Res. 1997, 762, 12-18. [CrossRef]

279. Balogh, S.A.; McDowell, C.S.; Stavnezer, A.J.; Denenberg, V.H. A behavioral and neuroanatomical assessment of an inbred substrain of 129 mice with behavioral comparisons to C57BL/6J mice. Brain Res. 1999, 836, 38-48. [CrossRef]

280. Gerlai, R. Gene-targeting studies of mammalian behavior: Is it the mutation or the background genotype? Trends Neurosci. 1996, 19, 177-181. [CrossRef]

281. Wolfer, D.P.; Muller, U.; Stagliar, M.; Lipp, H.P. Assessing the effects of the 129/Sc genetic background on swimming navigation learning in transgenic mutants: A study using mice with a modified $\beta$-amyloid precursor protein gene. Brain Res. 1997, 771, 1-13. [CrossRef]

282. Takeda, T. Senescence-accelerated mouse (SAM) with special references to neurodegeneration models, SAMP8 and SAMP10 mice. Neurochem. Res. 2009, 34, 639-659. [CrossRef] [PubMed]

283. Ma, Q.; Qiang, J.; Gu, P.; Wang, Y.; Geng, Y.; Wang, M. Age-related autophagy alterations in the brain of senescence accelerated mouse prone 8 (SAMP8) mice. Exp. Gerontol. 2011, 46, 533-541. [CrossRef] [PubMed]

284. Alvarez-Garcia, O.; Vega-Naredo, I.; Sierra, V.; Caballero, B.; Tomas-Zapico, C.; Camins, A.; Garcia, J.J.; Pallas, M.; Coto-Montes, A. Elevated oxidative stress in the brain of senescence-accelerated mice at 5 months of age. Biogerontology 2006, 7, 43-52. [CrossRef] [PubMed]

285. Morley, J.E.; Farr, S.A.; Kumar, V.B.; Armbrecht, H.J. The SAMP8 mouse: A model to develop therapeutic interventions for Alzheimer's disease. Curr. Pharm. Des. 2012, 18, 1123-1130. [CrossRef] [PubMed]

286. Li, M.; Inaba, M.; Guo, K.; Abraham, N.G.; Ikehara, S. Amelioration of cognitive ability in senescence-accelerated mouse prone 8 (SAMP8) by intra-bone marrow-bone marrow transplantation. Neurosci. Lett. 2009, 465, 36-40. [CrossRef] [PubMed]

287. Chouliaras, L.; Rutten, B.P.; Kenis, G.; Peerbooms, O.; Visser, P.J.; Verhey, F.; van Os, J.; Steinbusch, H.W.; van den Hove, D.L. Epigenetic regulation in the pathophysiology of Alzheimer's disease. Prog. Neurobiol. 2010, 90, 498-510. [CrossRef] [PubMed]

288. Lee, H.J.; Lee, J.K.; Lee, H.; Carter, J.E.; Chang, J.W.; Oh, W.; Yang, Y.S.; Suh, J.G.; Lee, B.H.; Jin, H.K.; et al. Human umbilical cord blood-derived mesenchymal stem cells improve neuropathology and cognitive impairment in an Alzheimer's disease mouse model through modulation of neuroinflammation. Neurobiol. Aging 2012, 33, 588-602. [CrossRef] [PubMed]

289. Park, H.J.; Shin, J.Y.; Lee, B.R.; Kim, H.O.; Lee, P.H. Mesenchymal stem cells augment neurogenesis in the subventricular zone and enhance differentiation of neural precursor cells into dopaminergic neurons in the substantia nigra of a parkinsonian model. Cell Transpl. 2012, 21, 1629-1640. [CrossRef] [PubMed]

290. Martinez-Morales, P.L.; Revilla, A.; Ocana, I.; Gonzalez, C.; Sainz, P.; McGuire, D.; Liste, I. Progress in stem cell therapy for major human neurological disorders. Stem Cell Rev. 2013, 9, 685-699. [CrossRef] [PubMed]

291. Forostyak, S.; Homola, A.; Turnovcova, K.; Svitil, P.; Jendelova, P.; Sykova, E. Intrathecal delivery of mesenchymal stromal cells protects the structure of altered perineuronal nets in SOD1 rats and amends the course of ALS. Stem Cells 2014, 32, 3163-3172. [CrossRef] [PubMed]

292. Mazzini, L.; Vercelli, A.; Ferrero, I.; Boido, M.; Cantello, R.; Fagioli, F. Transplantation of mesenchymal stem cells in ALS. Prog. Brain Res. 2012, 201, 333-359. [PubMed]

293. Hayashi, T.; Wakao, S.; Kitada, M.; Ose, T.; Watabe, H.; Kuroda, Y.; Mitsunaga, K.; Matsuse, D.; Shigemoto, T.; Ito, A.; et al. Autologous mesenchymal stem cell-derived dopaminergic neurons function in parkinsonian macaques. J. Clin. Investig. 2013, 123, 272-284. [CrossRef] [PubMed]

294. Glavaski-Joksimovic, A.; Bohn, M.C. Mesenchymal stem cells and neuroregeneration in Parkinson's disease. Exp. Neurol. 2013, 247, 25-38. [CrossRef] [PubMed]

295. Kern, S.; Eichler, H.; Stoeve, J.; Kluter, H.; Bieback, K. Comparative analysis of mesenchymal stem cells from bone marrow, umbilical cord blood, or adipose tissue. Stem Cells 2006, 24, 1294-1301. [CrossRef] [PubMed]

296. Kassem, M. Abdallah, B.M. Human bone-marrow-derived mesenchymal stem cells: Biological characteristics and potential role in therapy of degenerative diseases. Cell Tissue Res. 2008, 331, 157-163. [CrossRef] [PubMed] 
297. Fukuchi, Y.; Nakajima, H.; Sugiyama, D.; Hirose, I.; Kitamura, T.; Tsuji, K. Human placenta-derived cells have mesenchymal stem/progenitor cell potential. Stem Cells 2004, 22, 649-658. [CrossRef] [PubMed]

298. Wyse, R.D.; Dunbar, G.L.; Rossignol, J. Use of genetically modified mesenchymal stem cells to treat neurodegenerative diseases. Int. J. Mol. Sci. 2014, 15, 1719-1745. [CrossRef] [PubMed]

299. Harting, M.T.; Jimenez, F.; Xue, H.; Fischer, U.M.; Baumgartner, J.; Dash, P.K.; Cox, C.S. Intravenous mesenchymal stem cell therapy for traumatic brain injury. J. Neurosurg. 2009, 110, 1189-1197. [CrossRef] [PubMed]

300. Danielyan, L.; Schafer, R.; von Ameln-Mayerhofer, A.; Buadze, M.; Geisler, J.; Klopher, T.; Burkhardt, U.; Proksch, B.; Verleysdonk, S.; Ayturan, M.; et al. Intranasal delivery of cells to the brain. Eur. J. Cell Biol. 2009, 88, 315-324. [CrossRef] [PubMed]

301. Paul, C.; Samdani, A.F.; Betz, R.R.; Fischer, I.; Neuhuber, B. Grafting of human bone marrow stromal cells into spinal cord injury: A comparison of delivery methods. Spine 2009, 34, 328-334. [CrossRef] [PubMed]

302. Urdzikova, L.M.; Ruzicka, J.; LaBagnara, M.; Karova, K.; Kubinova, S.; Jirakova, K.; Murali, R.; Sykova, E.; Jhanwar-Uniyal, M.; Jendelova, P. Human mesenchymal stem cells modulate inflammatory cytokines after spinal cord injury in rat. Int. J. Mol. Sci. 2014, 15, 11275-11293. [CrossRef] [PubMed]

303. Yun, H.M.; Kim, H.S.; Park, K.R.; Shin, J.M.; Kang, A.R.; Lee, K.; Song, S.; Kim, Y.B.; Han, S.B.; Chung, H.M.; et al. Placenta-derived mesenchymal stem cells improve memory dysfunction in an A 11-42-induced mouse model of Alzheimer's disease. Cell Death Dis. 2013, 4, e958. [CrossRef] [PubMed]

304. Ikehara, S.; Li, M. Stem cell transplantation improves aging-related disease. Front. Cell Dev. Biol. $2014,2,16$. [CrossRef] [PubMed]

305. Lee, J.K.; Jin, H.K.; Bae, J.S. Bone marrow-derived mesenchymal stem cells reduce brain amyloid- $\beta$ deposition and accelerate the activation of microglia in an acutely induced Alzheimer's disease mouse model. Neurosci. Lett. 2009, 450, 136-141. [CrossRef] [PubMed]

306. Lee, J.K.; Jin, H.K.; Endo, S.; Schuchman, E.H.; Carter, J.E.; Bae, J.S. Intracerebral transplantation of bone marrow-derived mesenchymal stem cells reduces amyloid- $\beta$ deposition and rescues memory deficits in Alzheimer's disease mice by modulation of immune responses. Stem Cells 2010, 28, 329-343. [CrossRef] [PubMed]

307. Butovsky, O.; Talpalar, A.E.; Ben-Yaakov, K.; Schwartz, M. Activation of microglia by aggregated $\beta$-amyloid or lipopolysaccharide impairs MHC-II expression and renders them cytotoxic whereas IFN- $\gamma$ and IL-4 render them protective. Mol. Cell. Neurosci. 2005, 29, 381-393. [CrossRef] [PubMed]

308. Butovsky, O.; Koronyo-Hamaoui, M.; Kunis, G.; Ophir, E.; Landa, G.; Cohen, H.; Schwartz, M. Glatiramer acetate fights against Alzheimer's disease by inducing dendritic-like microglia expression insulin-like growth factor 1. Proc. Natl. Acad. Sci. USA 2006, 103, 11784-11789. [CrossRef] [PubMed]

309. Nemeth, K.; Leelahavanichkul, A.; Yuen, P.S.; Mayer, B.; Parmelee, A.; Doi, K.; Robey, P.G.; Leelahavanichkul, K.; Koller, B.H.; Brown, J.M.; et al. Bone marrow stromal cells attenuate sepsis via prostaglandin $\mathrm{E}(2)$-dependent reprogramming of host macrophages to increase their interleukin-10 production. Nat. Med. 2009, 15, 42-49. [CrossRef] [PubMed]

310. Chen, W.W.; Blurton-Jones, M. Can stem cells be used to treat or model Alzheimer disease? Stem Cells 2012 , 30, 2612-2618. [CrossRef] [PubMed]

311. Ma, S.; Xie, N.; Li, W.; Yuan, B.; Shi, Y.; Wang, Y. Immunobiology of mesenchymal stem cells. Cell Death Differ. 2014, 21, 216-225. [CrossRef] [PubMed]

312. Parr, A.M.; Kulbatski, I.; Tator, C.H. Transplantation of adult rat spinal cord stem/progenitor cells for spinal cord injury. J. Neurotrauma 2007, 24, 835-845. [CrossRef] [PubMed]

313. Munoz, J.R.; Stoutenger, B.R.; Robinson, A.P.; Spees, J.L.; Prockop, D.J. Human stem/progenitor cells from bone marrow promote neurogenesis of endogenous neural stem cells in the hippocampus of mice. Proc. Natl. Acad. Sci. USA 2005, 102, 18171-18176. [CrossRef] [PubMed]

314. Kan, I.; Barhum, Y.; Melamed, E.; Offen, D. Mesenchymal stem cells stimulate endogenous neurogenesis in the subventricular zone of adult mice. Stem Cell Rev. 2011, 7, 404-412. [CrossRef] [PubMed]

315. Kim, S.; Chang, K.A.; Kim, J.A.; Park, H.G.; Ra, J.C.; Kim, H.S.; Suh, Y.H. The preventive and therapeutic effects of intravenous human adipose-derived stem cells in Alzheimer's disease mice. PLoS ONE 2012, 7, e45757. [CrossRef] [PubMed] 
316. Tfilin, M.; Sudai, E.; Merenlender, A.; Gispan, I.; Yadid, G.; Turgeman, G. Mesenchymal stem cells increase hippocampal neurogenesis and counteract depressive-like behavior. Mol. Psychiatry 2010, 15, 1164-1175. [CrossRef] [PubMed]

317. Lu, S.; Lu, C.; Han, Q.; Li, J.; Du, Z.; Liao, L.; Zhao, R.C. Adipose-derived mesenchymal stem cells protect PC12 cells from glutamate excitotoxicity-induced apoptosis by upregulation of XIAP through PI3-K/Akt activation. Toxicology 2011, 279, 189-195. [CrossRef] [PubMed]

318. Lois, C.; Alvarez-Buylla, A. Long-distance neuronal migration in the adult mammalian brain. Science 1994, 264, 1145-1148. [CrossRef] [PubMed]

319. Alvarez-Buylla, A.; Garcia-Verdugo, J.M.; Tramontin, A.D. A unified hypothesis on the lineage of neural stem cells. Nat. Rev. Neurosci. 2001, 2, 287-293. [CrossRef] [PubMed]

320. Cameron, H.A.; McKay, R.D. Adult neurogenesis produces a large pool of new granule cells in the dentate gyrus. J. Comp. Neurol. 2001, 435, 406-417. [CrossRef] [PubMed]

321. Zhao, C.; Deng, W.; Gage, F.H. Mechanisms and functional implications of adult neurogenesis. Cell 2008, 132, 645-660. [CrossRef] [PubMed]

322. Ahlenius, H.; Visan, V.; Kokaia, M.; Lindvall, O.; Kokaia, Z. Neural stem and progenitor cells retain their potential for proliferation and differentiation into functional neurons despite lower number in aged brain. J. Neurosci. 2009, 29, 4408-4419. [CrossRef] [PubMed]

323. Miranda, C.J.; Braun, L.; Jiang, Y.; Hester, M.E.; Zhang, L.; Riolo, M.; Wang, H.; Rao, M.; Altura, R.A.; Kaspar, B.K. Aging brain microenvironment decreases hippocampal neurogenesis through Wnt-mediated survivin signaling. Aging Cell 2012, 11, 542-552. [CrossRef] [PubMed]

324. Lee, S.W.; Clemenson, G.D.; Gage, F.H. New neurons in an aged brain. Behav. Brain Res. 2012, 227, $497-507$. [CrossRef] [PubMed]

325. Ferron, S.R.; Marques-Torrejon, M.A.; Mira, H.; Flores, I.; Taylor, K.; Blasco, M.A.; Farinas, I. Telomere shortening in neural stem cells disrupts neuronal differentiation and neuritogenesis. J. Neurosci. 2009, 29, 14394-14407. [CrossRef] [PubMed]

326. Blurton-Jones, M.; Kitazawa, M.; Martinez-Coria, H.; Castello, N.A.; Muller, F.J.; Loring, J.F.; Yamasaki, T.R.; Poon, W.W.; Green, K.N.; LaFerla, F.M. Neural stem cell improve cognition via BDNF in a transgenic model of Alzheimer disease. Proc. Natl. Acad. Sci. USA 2009, 106, 13594-13599. [CrossRef] [PubMed]

327. Sugaya, K. Possible use of autologous stem cell therapies for Alzheimer's disease. Curr. Alzheimer Res. 2005, 2, 367-376. [CrossRef] [PubMed]

328. Waldau, B.; Shetty, A.K. Behavior of neural stem cells in the Alzheimer brain. Cell. Mol. Life Sci. 2008, 65, 2372-2384. [CrossRef] [PubMed]

329. Rivera, F.J.; Siebzehnrubl, F.A.; Kandasamy, M.; Couillard-Despres, S.; Caioni, M.; Poehler, A.M.; Berninger, B.; Sandner, B.; Bogdahn, U.; Goetz, M.; et al. Mesenchymal stem cells promote oligodendroglial differentiation in hippocampal slice cultures. Cell. Physiol. Biochem. 2009, 24, 317-324. [CrossRef] [PubMed]

330. Stewart, C.R.; Stuart, L.M.; Wilkinson, K.; van Gils, J.M.; Deng, J.; Halle, A.; Rayner, K.J.; Boyer, L.; Zhong, R.; Frazier, W.A.; et al. CD36 ligands promote sterile inflammation through assembly of a toll like receptor 4 and 6 heterodimer. Nat. Immunol. 2010, 11, 155-161. [CrossRef] [PubMed]

331. Reed-Geaghan, E.G.; Savage, J.C.; Hise, A.G.; Landreth, G.E. CD14 and Toll-like receptors 2 and 4 are required for fibrillar A $\beta$-stimulated microglial activation. J. Neurosci. 2009, 29, 11982-11992. [CrossRef] [PubMed]

332. Lim, J.E.; Kou, J.; Song, M.; Pattanayak, A.; Jin, J.; Lalonde, R.; Fukuchi, K. MyD88 deficiency ameliorates $\beta$-amyloidosis in an animal model of AD. Am. J. Pathol. 2011, 179, 1095-1103. [CrossRef] [PubMed]

333. Malm, T.; Koistinaho, J.; Kanninen, K. Utilization of APPswe/PS1dE9 transgenic mice in research of Alzheimer's disease: Focus on gene therapy and cell-based therapy applications. Int. J. Alzheimers Dis. 2011, 2011. [CrossRef] [PubMed]

334. Fischer, W.; Wictorin, K.; Bjorklund, A.; Williams, L.P.; Varon, S.; Gage, F.H. Amelioration of cholinergic neuron atrophy and spatial memory impairment in aged rats by nerve growth factor. Nature 1987, 329, 65-68. [CrossRef] [PubMed]

335. Pan, W.; Banks, W.A.; Kastin, A.J. Permeability of the blood-brain barrier to neurotrophins. Brain Res. 1998, 788, 87-94. [CrossRef]

336. Williams, L.R. Hypophagia is induced by intracerebroventricular administration of nerve growth factor. Exp. Neurol. 1991, 113, 31-37. [CrossRef] 
337. Tuszynski, M.H.; Thal, L.; Pay, M.; Salmon, D.P.; Sang U, H.; Bakay, R.; Patel, P.; Blesch, A.; Vahlsing, H.L.; Ho, G.; et al. A phase 1 clinical trial of nerve growth factor gene therapy for Alzheimer disease. Nat. Med. 2005, 11, 551-555. [CrossRef] [PubMed]

338. Rafii, M.S.; Baumann, T.L.; Bakay, R.A.; Ostrove, J.M.; Siffert, J.; Fleisher, A.S.; Herzog, C.D.; Barba, D.; Pay, M.; Salmon, D.P.; et al. A phase 1 study of stereotactic gene delivery of AAV2-NGF for Alzheimer's disease. Alzheimers Dement. 2014, 10, 571-581. [CrossRef] [PubMed]

339. Nagahara, A.H.; Merrill, D.A.; Coppola, G.; Tsukada, S.; Schroeder, B.E.; Shaked, G.M.; Wang, L.; Blesch, A.; Kim, A.; Conner, J.M.; et al. Neuroprotective effects of brain-derived neurotrophic factor in rodent and primate models of Alzheimer's disease. Nat. Med. 2009, 15, 331-337. [CrossRef] [PubMed]

340. Connor, B.; Young, D.; Yan, Q.; Faull, R.L.; Synek, B.; Dragunow, M. Brain-derived neurotrophic factor is reduced in Alzheimer's disease. Mol. Brain Res. 1997, 49, 71-81. [CrossRef]

341. Blurton-Jones, M.; Spencer, B.; Michael, S.; Castello, N.A.; Agazaryan, A.A.; Davis, J.L.; Muller, F.J.; Loring, J.F.; Masliah, E.; LaFerla, F.M. Neural stem cells genetically-modified to express neprilysin reduce pathology in Alzheimer transgenic models. Stem Cell Res. Ther. 2014, 5, 46. [CrossRef] [PubMed]

342. Takahashi, K.; Yamanaka, S. Induction of pluripotent stem cells from mouse embryonic and adult fibroblast cultures by defined factors. Cell 2006, 126, 663-676. [CrossRef] [PubMed]

343. Lapasset, L.; Milhavet, O.; Prieur, A.; Besnard, E.; Babled, A.; Ait-Hamou, N.; Leschik, J.; Pellestor, F.; Ramirez, J.M.; de Vos, J.; et al. Rejuvenating senescent and centenarian human cells by reprogramming through the pluripotent state. Genes Dev. 2011, 25, 2248-2253. [CrossRef] [PubMed]

344. Yagi, T.; Kosakai, A.; Ito, D.; Okada, Y.; Akamatsu, W.; Nihei, Y.; Nabetani, A.; Ishikawa, F.; Arai, Y.; Hirose, N.; et al. Establishment of induced pluripotent stem cells from centenarians for neurodegenerative disease research. PLoS ONE 2012, 7, e41572. [CrossRef] [PubMed]

345. Yagi, T.; Ito, D.; Okada, Y.; Akamatsu, W.; Nihei, Y.; Yoshizaki, T.; Yamanaka, S.; Okano, H.; Suzuki, N. Modeling familial Alzheimer's disease with induced pluripotent stem cells. Hum. Mol. Genet. 2011, 20, 4530-4539. [CrossRef] [PubMed]

346. Israel, M.A.; Yuan, S.H.; Bardy, C.; Reyna, S.M.; Mu, Y.; Herrera, C.; Hefferan, M.P.; van Gorp, S.; Nazor, K.L.; Bascolo, F.S.; et al. Probing sporadic and familial Alzheimer's disease using induced pluripotent stem cells. Nature 2012, 482, 216-220. [CrossRef] [PubMed]

347. Isobe, K.; Cheng, Z.; Nishio, N.; Suganya, T.; Tanaka, Y.; Ito, S. iPSCs, aging and age-related diseases. N. Biotechnol. 2014, 31, 411-421. [CrossRef] [PubMed]

348. Blasco, M.A. Telomere length, stem cells and aging. Nat. Chem. Biol. 2007, 3, 640-649. [CrossRef] [PubMed]

349. Marion, R.M.; Strati, K.; Li, H.; Tejera, A.; Schoeftner, S.; Ortega, S.; Serrano, M.; Blasco, M.A. Telomeres acquire embryonic stem cell characteristics in induced pluripotent stem cells. Cell Stem Cell 2009, 4, 141-154. [CrossRef] [PubMed]

350. Huang, J.; Wang, F.; Okuka, M.; Liu, N.; Ji, G.; Ye, X.; Zuo, B.; Li, M.; Liang, P.; Ge, W.W.; et al. Association of telomere length with authentic pluripotency of ES/iPS cells. Cell Res. 2011, 21, 779-792. [CrossRef] [PubMed]

351. Golde, T.E.; Miller, V.M. Proteinopathy-induced neuronal senescence: A hypothesis for brain failure in Alzheimer's and other neurodegenerative diseases. Alzheimers Res. Ther. 2009, 1, 5. [CrossRef] [PubMed]

352. Hunter, S.; Arendt, T.; Brayne, C. The senescence hypothesis of disease progression in Alzheimer's disease: An integrated matrix of disease pathways for FAD and SAD. Mol. Neurobiol. 2013, 48, 556-570. [CrossRef] [PubMed]

353. Amemori, T.; Ermakova, I.V.; Buresova, O.; Zigova, T.; Racekova, E.; Bures, J. Brain transplants enhance rather than reduce the impairment of spatial memory and olfaction in bulbectomized rats. Behav. Neurosci. 1989, 103, 61-70. [CrossRef] [PubMed]

354. Vorhees, C.V.; Williams, M.T. Morris water maze: Procedures for assessing spatial and related forms of learning and memory. Nat. Protoc. 2006, 1, 848-858. [CrossRef] [PubMed]

(C) 2015 by the authors; licensee MDPI, Basel, Switzerland. This article is an open access article distributed under the terms and conditions of the Creative Commons by Attribution (CC-BY) license (http://creativecommons.org/licenses/by/4.0/). 